\title{
Erodibility Study Of Passaic River Sediments Using USACE Sedflume
}

\author{
By Thomas D. Borrowman, Ernest R. Smith, Joseph Z. Gailani, \\ and Larry Caviness \\ US Army Engineer Research and Development Center \\ 3909 Halls Ferry Road \\ Vicksburg, MS 39180-6199
}

Prepared for:

U.S. Army Engineer District, Kansas City

Kansas City, MO

and

U.S. Environmental Protection Agency

Region II

July 2006 


\section{Contents}

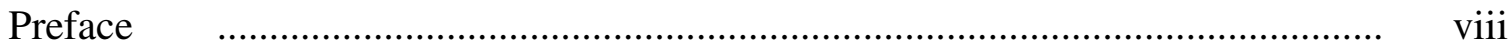

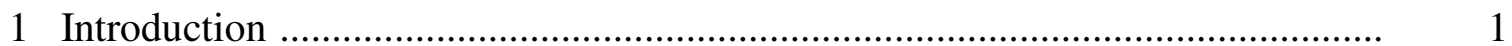

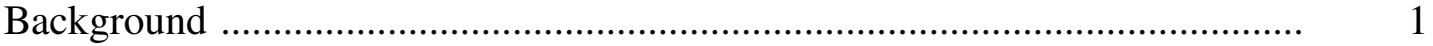

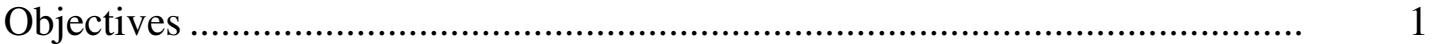

Nomenclature ................................................................................... 2

Report Organization...................................................................................... 2

2 Sedflume Description and Test Procedures ............................................................

Core Collection and Preparation......................................................................

Description of Sedflume ...............................................................................

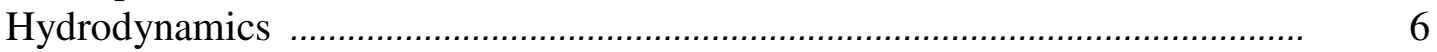

Sediment Erosion Rate Measurements ............................................................

Measurements of Sediment Bulk Properties....................................................... 8

Bulk Density Measurements ..................................................................

Particle-Size Distribution Measurements ............................................... $\quad 10$

Organic Content Measurements ............................................................ 10

3 Erosion Rate Experiment and Bulk Property Results .......................................... 11

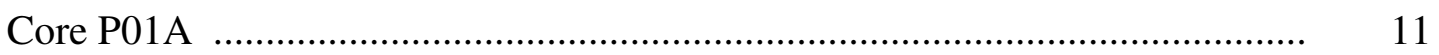

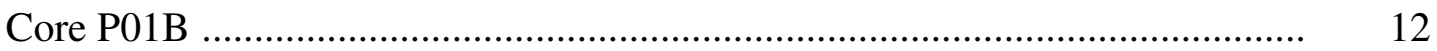

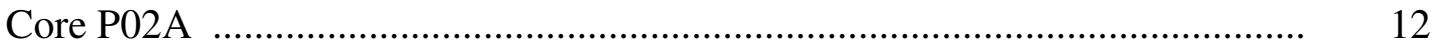

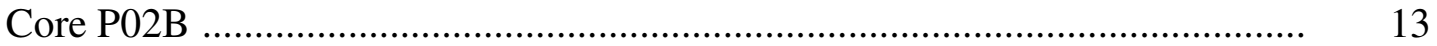

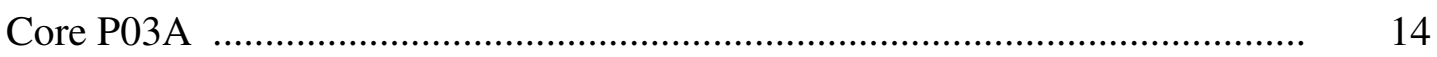

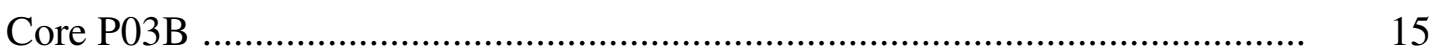

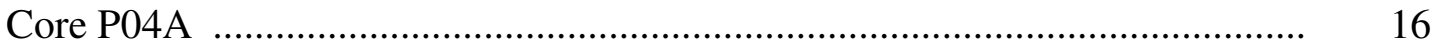

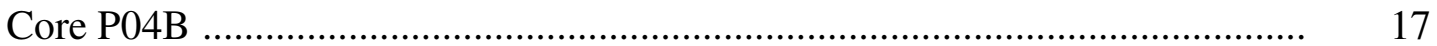

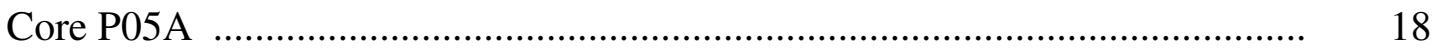

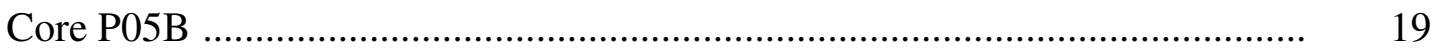

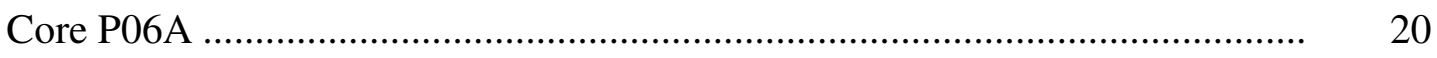

Core P06B ……………………………………........................ 20

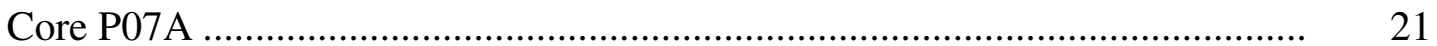

Core P07B .................................................................................... 22

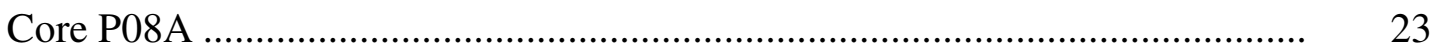




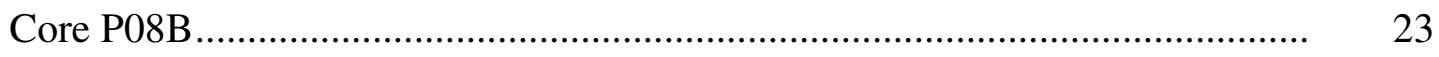

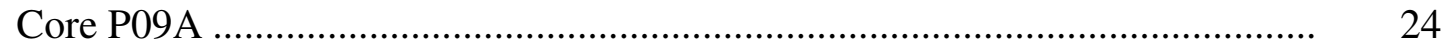

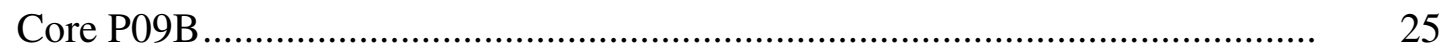

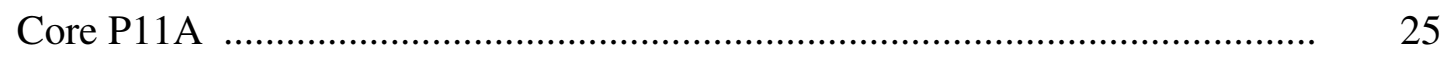

Core P11B …............................................................................... 26

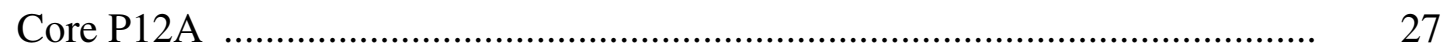

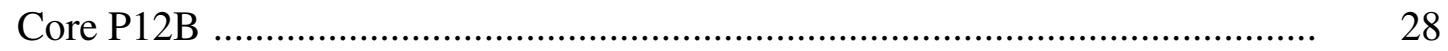

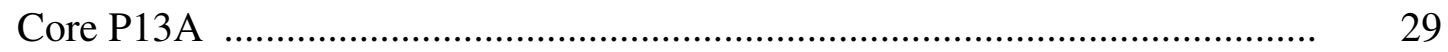

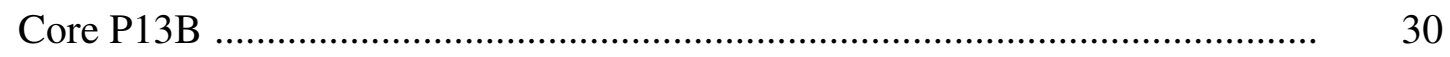

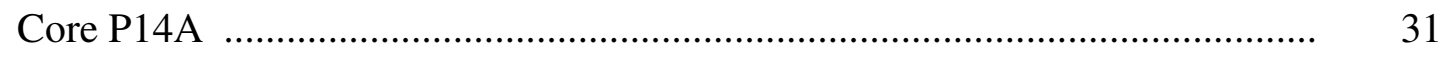

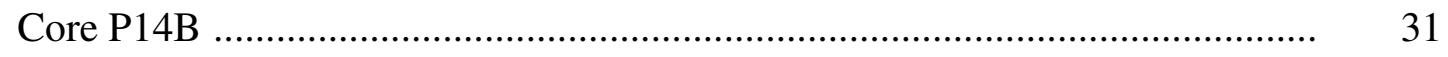

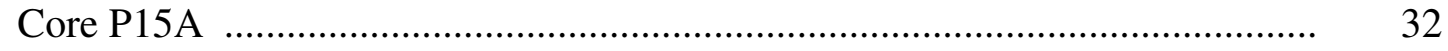

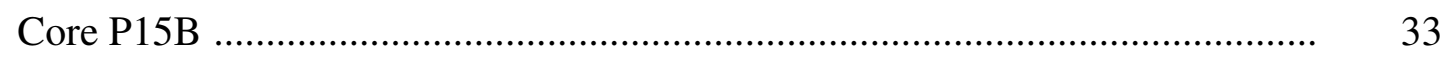

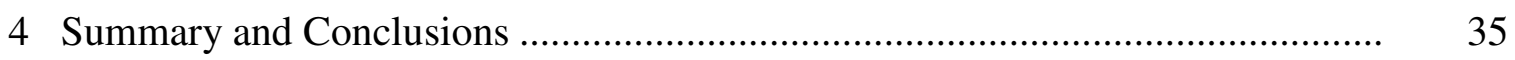

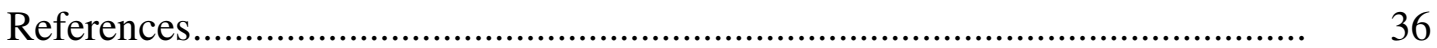




\section{List of Figures}

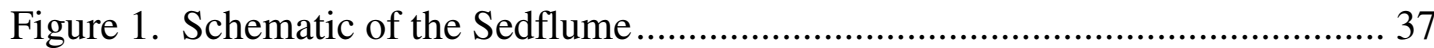

Figure 2. Site map for Lower Passaic Restoration Project ...................................... 38

Figure 3. Cores P01A and P01B bulk density profiles ........................................... 39

Figure 4. Cores P01A and P01B organic content profiles ....................................... 39

Figure 5. Cores P01A and P01B percent clay and fines content profiles ................ 40

Figure 6. Core P01A erosion rate versus shear stress results. ................................. 40

Figure 7. Core P01B erosion rate versus shear stress results................................... 41

Figure 8. Cores P02A and P02B bulk density profiles ........................................... 41

Figure 9. Cores P02A and P02B organic content profiles ..................................... 42

Figure 10. Cores P02A and P02B percent clay and fines content profiles .............. 42

Figure 11. Core P02A erosion rate versus shear stress results. ............................... 43

Figure 12. Core P02B erosion rate versus shear stress results.................................. 43

Figure 13. Cores P03A and P03B bulk density profiles ........................................ 44

Figure 14. Cores P03A and P03B organic content profiles ..................................... 44

Figure 15. Cores P03A and P03B percent clay and fines content profiles .............. 45

Figure 16. Core P03A erosion rate versus shear stress results. ............................... 45

Figure 17. Core P03B erosion rate versus shear stress results................................. 46

Figure 18. Cores P04A and P04B bulk density profiles ....................................... 46

Figure 19. Cores P04A and P04B organic content profiles ..................................... 47

Figure 20. Cores P04A and P04B percent clay and fines content profiles .............. 47

Figure 21. Core P04A erosion rate versus shear stress results. .............................. 48 
Figure 22. Core P04B erosion rate versus shear stress results................................. 48

Figure 23. Cores P05A and P05B bulk density profiles .......................................... 49

Figure 24. Cores P05A and P05B organic content profiles .................................... 49

Figure 25. Cores P05A and P05B percent clay and fines content profiles .............. 50

Figure 26. Core P05A erosion rate versus shear stress results. .............................. 50

Figure 27. Core P05B erosion rate versus shear stress results................................. 51

Figure 28. Cores P06A and P06B bulk density profiles ......................................... 51

Figure 29. Cores P06A and P06B organic content profiles .................................... 52

Figure 30. Cores P06A and P06B percent clay and fines content profiles .............. 52

Figure 31. Core P06A erosion rate versus shear stress results. .............................. 53

Figure 32. Core P06B erosion rate versus shear stress results................................. 53

Figure 33. Cores P07A and P07B bulk density profiles ......................................... 54

Figure 34. Cores P07A and P07B organic content profiles .................................... 54

Figure 35. Cores P07A and P07B percent clay and fines content profiles .............. 55

Figure 36. Core P07A erosion rate versus shear stress results. .............................. 55

Figure 37. Core P07B erosion rate versus shear stress results................................ 56

Figure 38. Cores P08A and P08B bulk density profiles ........................................ 56

Figure 39. Cores P08A and P08B organic content profiles .................................... 57

Figure 40. Cores P08A and P08B percent clay and fines content profiles .............. 57

Figure 41. Core P08A erosion rate versus shear stress results. ............................. 58

Figure 42. Core P08B erosion rate versus shear stress results................................58

Figure 43. Cores P09A and P09B bulk density profiles ......................................... 59

Figure 44. Cores P09A and P09B organic content profiles .................................... 59 
Figure 45. Cores P09A and P09B percent clay and fines content profiles 60

Figure 46. Core P09A erosion rate versus shear stress results. ..............................60

Figure 47. Core P09B erosion rate versus shear stress results............................. 61

Figure 48. Cores P11A and P11B bulk density profiles .................................. 61

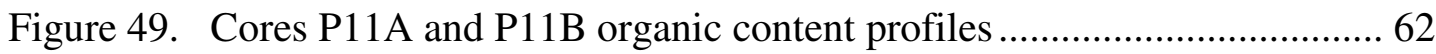

Figure 50. Cores P11A and P11B percent clay and fines content profiles ............. 62

Figure 51. Core P11A erosion rate versus shear stress results. .............................63 63

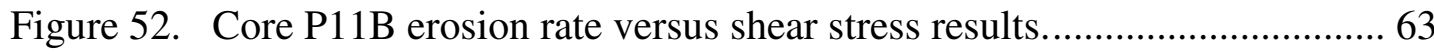

Figure 53. Cores P12A and P12B bulk density profiles ................................... 64

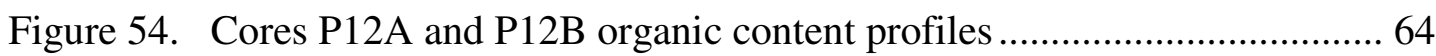

Figure 55. Cores P12A and P12B percent clay and fines content profiles ............. 65

Figure 56. Core P12A erosion rate versus shear stress results. ........................... 65

Figure 57. Core P12B erosion rate versus shear stress results..............................66

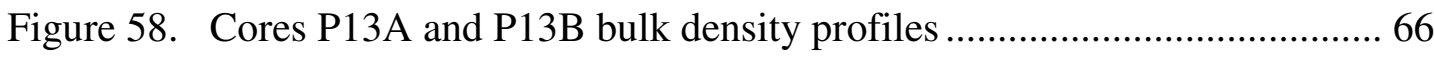

Figure 59. Cores P13A and P13B organic content profiles .............................. 67

Figure 60. Cores P13A and P13B percent clay and fines content profiles ............. 67

Figure 61. Core P13A erosion rate versus shear stress results. ............................6 68

Figure 62. Core P13B erosion rate versus shear stress results............................. 68

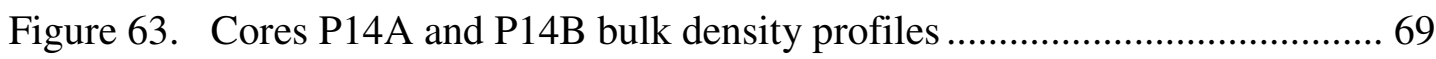

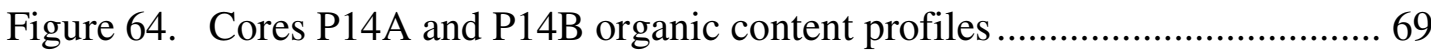

Figure 65. Cores P14A and P14B percent clay and fines content profiles ............. 70

Figure 66. Core P14A erosion rate versus shear stress results. ........................... 70

Figure 67. Core P14B erosion rate versus shear stress results............................ 71 
Figure 68. Cores P15A and P15B bulk density profiles ................................. 71

Figure 69. Cores P15A and P15B organic content profiles .............................. 72

Figure 70. Cores P15A and P15B percent clay and fines content profiles ............. 72

Figure 71. Core P15A erosion rate versus shear stress results. ........................... 73

Figure 72. Core P15B erosion rate versus shear stress results. .......................... 73 


\section{Preface}

This report presents the results and analysis of erodibility experiments performed on 28 cores from the Passaic River, NJ in May and June, 2005 as part of the Lower Passaic River Restoration Project, a joint study being conducted by the U.S. Environmental Protection Agency (EPA), U.S. Army Corps of Engineers (USACE), and New Jersey Department of Transportation. The joint study consists of a Superfund remedial investigation and feasibility study combined with a Water Resources Development Act feasibility study. Members of the U.S. Army Corps of Engineers (USACE) Environmental Laboratory (EL) and Coastal and Hydraulics Laboratory (CHL), U.S. Army Engineer Research and Development Center (ERDC) at the Waterways Experiment Station (WES) conducted this work. Funding for ERDC was provided through the USACE Kansas City District. The Kansas City District point of contact is Elizabeth A. Buckrucker.

The report was prepared by Mr. Thomas D. Borrowman and Ms. Cheryl M. Lloyd, Environmental Engineering Branch (EEB), Environmental Processes and Engineering Division (EPED), EL, Mr. Ernest R. Smith, and Dr. Joseph Z. Gailani, Coastal Processes Branch (HF-C), Flood and Storm Protection Division (HF), CHL. Laboratory work was conducted by Mr. Richard Hudson, EEB.

This study was conducted under the direct supervision of Mr. Bruce A Ebersole, Chief, HF, and under the general supervision of Mr. Thomas W. Richardson, Director, CHL. Dr. James R. Houston was Director, ERDC, and COL James R. Rowan, EN, was Commander at the time of this study.

This report should be cited as follows:

(2006). "Erodibility Study of Passaic River Sediments," Project Report, U.S. Army Engineer Research and Development Center, Vicksburg, MS. 


\section{Introduction}

\section{Background}

Extensive pollution is present in Passaic River, NJ sediments due to heavy industrial use and urban runoff. Pursuant to the U.S. Environmental Protection Agency's (EPA) Superfund remedial investigation (RI) being performed as part of the Lower Passaic River Restoration Project, it was necessary to evaluate the erodibility of a 15-mile stretch of the Lower Passaic River to assess remediation options and prioritize remediation sites.

Cohesive sediment erosion differs significantly from coarse-grained, non-cohesive (sand) erosion phenomena. Non-cohesive sediment erosion can generally be quantified based on applied shear stress and grain size distribution. Cohesive sediment erosion is related to these factors and to sediment bulk properties, including bulk density, mineralogy, pore-water chemistry, and organic content. Although it is known qualitatively how many of these parameters may affect erosion, a priori quantitative methods of relating cohesive sediment erosion to these bulk properties are not available. Methods have been developed to determine a site-specific relationship between erosion rate and shear stress using rate results obtained through sediment sample testing on the U.S. Army Corps of Engineers' (USACE) Sedflume.

\section{Objectives}

The objectives of this study were to extract a total of 28 sediment cores $30-60 \mathrm{~cm}$ deep from 14 locations along the Passaic River in order to

1. Measure the erodibility as a function of depth for different shear stresses using the Sedflume

2. Measure and analyze bulk density, organic content, and grain-size distribution data vs. depth for the Sedflume coring sites

3. Qualitatively analyze the response of erosion rates to changes in bulk properties. 


\section{Nomenclature}

A system of naming cores based on their site of origin and other characteristics was developed for this study. For convenience, this system is employed extensively throughout this report. The prefix "P" stands for Passaic River and was originally included to uniquely identify these samples as Passaic River sediments during laboratory analysis. The set of numbers, "01" through " 15 ", denotes whether a core was extracted from Site 1 through Site 15, respectively. Finally, "A" or "B" distinguishes between replicate cores from the same location. Figure 2 shows a map of the coring locations along the Lower Passaic River. Table 1 presents the date and time of core extraction, sediment core lengths, date the core was eroded, location of the sediment core, and depth of water in which the cores were extracted. Although each station's replicate cores are listed at the same location and depth of water, the two cores were extracted some distance apart. The distance, and at times depth, also varied. Table 1 presents the most representative information available.

\section{Report Organization}

Chapter 2 of this report contains descriptions of the sediment coring method, the Sedflume, and Sedflume standard operating procedures. This chapter also includes description of methods for measuring bulk properties. Chapter 3 presents the bulk property and erosion rate results for the 28 sediment cores tested, as well as discussion and conclusions regarding the correlation of erosion rate results to sediment bulk properties. Chapter 4 contains a discussion and conclusions regarding the correlation of erosion rate results to sediment bulk properties. Chapter 4 also presents a summary and conclusions regarding the findings of this study. A list of references for this report follows Chapter 4. 


\begin{tabular}{|c|c|c|c|c|c|}
\hline Station & $\begin{array}{l}\text { Date/Time } \\
\text { Extracted }\end{array}$ & $\begin{array}{c}\text { Core } \\
\text { Length }(\mathrm{cm})\end{array}$ & $\begin{array}{c}\text { Date } \\
\text { Eroded }\end{array}$ & Location & $\begin{array}{c}\text { Water } \\
\text { Depth } \\
\text { (m) }\end{array}$ \\
\hline $1 \mathrm{~A}$ & \multirow{2}{*}{$\begin{array}{c}05 / 17 / 2005 \\
1400\end{array}$} & 24 & "06/06/2005 & "N40.71175 & \multirow{2}{*}{8.2} \\
\hline $1 \mathrm{~B}$ & & 22.75 & $06 / 16 / 2005$ & W74.12208 & \\
\hline $2 \mathrm{~A}$ & \multirow{2}{*}{$\begin{array}{c}05 / 17 / 2005 \\
1630\end{array}$} & 50 & $06 / 16 / 2005$ & N40.72441 & \multirow{2}{*}{5.5} \\
\hline $2 \mathrm{~B}$ & & 46.5 & $06 / 07 / 2005$ & W74.12088 & \\
\hline $3 \mathrm{~A}$ & \multirow{2}{*}{$\begin{array}{c}05 / 18 / 2005 \\
1215\end{array}$} & 47 & $06 / 09 / 2005$ & N40.740198 & \multirow{2}{*}{2.4} \\
\hline $3 \mathrm{~B}$ & & 43 & $06 / 17 / 2005$ & W74.11885 & \\
\hline $4 \mathrm{~A}$ & \multirow{2}{*}{$\begin{array}{c}05 / 18 / 2005 \\
0940\end{array}$} & 48 & $06 / 17 / 2005$ & $\mathrm{~N} 40.74055$ & \multirow{2}{*}{3.6} \\
\hline $4 \mathrm{~B}$ & & 44.5 & $06 / 09 / 2005$ & W74.11895 & \\
\hline $5 \mathrm{~A}$ & \multirow{2}{*}{$\begin{array}{c}05 / 18 / 2005 \\
1213\end{array}$} & 50 & $06 / 10 / 2005$ & $\mathrm{~N} 40.74040$ & \multirow{2}{*}{1.8} \\
\hline $5 B$ & & 43.5 & $06 / 18 / 2005$ & W74.13931 & \\
\hline $6 \mathrm{~A}$ & \multirow{2}{*}{$\begin{array}{c}05 / 19 / 2005 \\
1236\end{array}$} & 41 & $06 / 11 / 2005$ & N40.74156 & \multirow{2}{*}{3.1} \\
\hline $6 \mathrm{~B}$ & & 46.5 & $06 / 18 / 2005$ & W74.13439 & \\
\hline $7 \mathrm{~A}$ & \multirow{2}{*}{$\begin{array}{c}05 / 19 / 2005 \\
1250 \\
\end{array}$} & 40 & $06 / 11 / 2005$ & N40.74142 & \multirow{2}{*}{2.1} \\
\hline $7 \mathrm{~B}$ & & 39 & $06 / 19 / 2005$ & W74.13454 & \\
\hline $8 \mathrm{~A}$ & \multirow{2}{*}{$\begin{array}{c}05 / 18 / 2005 \\
1400\end{array}$} & 34.5 & $06 / 22 / 2005$ & $\mathrm{~N} 40.73387$ & \multirow{2}{*}{5.5} \\
\hline $8 \mathrm{~B}$ & & 33 & $06 / 12 / 2005$ & W7414894 & \\
\hline $9 \mathrm{~A}$ & \multirow{2}{*}{$\begin{array}{c}05 / 17 / 2005 \\
1548\end{array}$} & 65.5 & $06 / 15 / 2005$ & $\mathrm{~N} 40.73400$ & \multirow{2}{*}{2.1} \\
\hline $9 \mathrm{~B}$ & & 45.2 & $06 / 22 / 2005$ & W74.15616 & \\
\hline $10 \mathrm{~A}$ & \multirow{2}{*}{\multicolumn{5}{|c|}{ Cores could not be captured successfully ${ }^{1}$}} \\
\hline $10 \mathrm{~B}$ & & & & & \\
\hline $11 \mathrm{~A}$ & \multirow{2}{*}{$\begin{array}{c}05 / 18 / 2005 \\
1630\end{array}$} & 42.5 & $06 / 12 / 2005$ & N40.74577 & \multirow{2}{*}{5.2} \\
\hline 11B & & 51.5 & $06 / 23 / 2005$ & W74.16591 & \\
\hline $12 \mathrm{~A}$ & \multirow{2}{*}{$\begin{array}{c}05 / 19 / 2005 \\
1236 \\
\end{array}$} & 47 & $06 / 13 / 2005$ & N40.76400 & \multirow{2}{*}{3.1} \\
\hline 12B & & 46 & $06 / 24 / 2005$ & W74.16010 & \\
\hline $13 \mathrm{~A}$ & \multirow{2}{*}{$\begin{array}{c}05 / 17 / 2005 \\
1024\end{array}$} & 49.5 & $06 / 14 / 2005$ & N40.81793 & \multirow{2}{*}{1.5} \\
\hline 13B & & 44 & $06 / 24 / 2005$ & W74.13080 & \\
\hline $14 \mathrm{~A}$ & \multirow{2}{*}{$\begin{array}{c}05 / 17 / 2005 \\
1024\end{array}$} & 34 & $06 / 15 / 2005$ & N40.85859 & \multirow{2}{*}{1.3} \\
\hline 14B & & 33.5 & $06 / 23 / 2006$ & W74.11892 & \\
\hline $15 \mathrm{~A}$ & \multirow{2}{*}{$\begin{array}{c}05 / 20 / 2005 \\
1236\end{array}$} & 50 & $05 / 23 / 2005$ & N40.85983 & \multirow{2}{*}{1.8} \\
\hline $15 \mathrm{~B}$ & & 47.5 & $05 / 23 / 2006$ & W74.11538 & \\
\hline
\end{tabular}




\section{Sedflume Description and Procedures}

Sedflume is designed to measure erosion rates for cohesive sediments. Sediment samples (cores) are generally extracted from the sediment bed. Great care is taken to minimize disturbance of the sediments in the core because this could alter erosion characteristics. Housing Sedflume in a self-contained mobile laboratory minimizes transport of cores. The mobile laboratory is a 24' trailer that includes a generator and all necessary equipment to perform Sedflume experiments. During May and June, 2005, this mobile laboratory was based at the Malcom Pirnie Passaic River field office site to perform erosion experiments on sediment core samples extracted from the river. Locating the flume at this site minimized core disturbance due to transport. The site allowed convenient drop-off for cores collected by boat as well as access to water both for supply and discharge purposes. Sedflume effluent was allowed to settle in large tanks for at least 24 hours before being discharged back into the Passaic River. Bulk density, organic content, and grain-size samples were collected incrementally in each core. Bulk property measurements were performed at the USACE Environmental Laboratory Hazardous Waste Research Center in Vicksburg, Mississippi.

\section{Core Collection and Preparation}

Sediment cores tested in Sedflume were relatively undisturbed cores taken from the 14 field sites. Lexan coring tubes, $10 \mathrm{~cm}$ in diameter, were manually pushed directly into the sediment bed to the maximum possible depth. In deeper water, a box core was used to bring a sediment bed sample onto the boat deck and the Lexan tubes were used to subsample the box core sample. Water was collected from the Passaic River and carefully decanted on top of the sediment cores to maintain core integrity until Sedflume testing was performed. To minimize vibrations that would alter the sediment particle structure, cores were stored in a 40-gallon barrel filled with cool water both on the sampling vessel and cool water with ice (replenished daily) on shore. 


\section{Description of Sedflume}

The purpose of the Sedflume is to measure the variability of erosion rates with depth of relatively undisturbed core samples extracted from a site. Erosion rate variation with depth measured in the Sedflume is important in quantifying sediment stability and movement. Sedflume measurements are generally considered the best method to quantify these erosion processes and their variation with depth.

Sedflume is a straight flume that has a test section with an open bottom through which a rectangular or circular cross-section coring tube containing sediment can be inserted (Figure 1). The flume used in these experiments is similar to the flume developed by researchers at the University of California at Santa Barbara (McNeil et al. 1996). The main components of the flume are the coring tube; the test section; an inlet section for uniform, fully developed, turbulent flow; a flow exit section; a water storage tank; and a pump to force water through the system (Figure 1). The coring tube, test section, inlet section, and exit section are made of clear acrylic or polycarbonate to allow observation of the sediment-water interactions. The coring tubes, which are up to $80 \mathrm{~cm}$ in length, may have either a $10-\mathrm{cm}$ by $15-\mathrm{cm}$ rectangular cross-section or a $10-\mathrm{cm}$ diameter circular cross-section. Circular cores were used for all Passaic River erosion experiments.

Water is pumped through the system from a storage tank that is hard-piped into the Sedflume test section. Water flows through a 5-cm diameter pipe to a flow converter, which distributes flow into the rectangular duct shown in Figure 1. As testing progresses, resuspended core sediments steadily accumulate in the system, eventually reaching a concentration at which visibility is impaired and testing cannot continue. It is then necessary to either filter the water or drain the supply tank and refill it with non-turbid water. For the Passaic River study, water was pumped from the river to the Sedflume supply tank. Sedflume effluent was pumped into one of two 5000-gallon storage tanks and held at least 24 hours before discharge to the river via sump pump.

At the beginning of each Sedflume erosion analysis, a plunger is placed in the bottom of the coring tube to prevent slippage of the sediment. The plunger is a circular disk with a rubber o-ring that creates a seal with the inside of the coring tube. The coring tube and the sediment it contains are inserted into the bottom of the test section. The core is always maintained in an upright position during loading. In the event that a sediment core has a sloped surface, the lowest edge of the core is oriented toward the source of flow to avoid surficial scouring of the core unless the higher edge has a flatter surface, in which case the higher edge is oriented toward the source of flow. An operator moves the sediment upward using a jack connected to the plunger. The jack is driven by motor, which is regulated with a switch. By this means, the sediment surface is raised and made level with the bottom of the test and inlet sections. The speed of the jack movement can be controlled at a variable rate in measurable increments as small as $0.5 \mathrm{~mm}$. 
Water is forced through the duct and the test section over the surface of the sediments. The shear produced by this flow, if great enough, causes the sediments to erode. As the sediments in the core erode, the core surface is moved upwards by the operator as necessary so that the sediment-water interface remains level with the bottom of the flume. Core height is measured as the distance from the sediment surface to the bottom of the sediment in the core (which corresponds to the plunger elevation). The sediment core is subjected to a specific flow rate corresponding to a particular shear stress. Erosion rates are obtained by measuring the remaining core length at different time intervals, measuring the plunger elevation difference between each successive measurement, and dividing by the time interval. The duration of each erosion test for a specified shear stress is dependent on the rate of erosion and generally is between 0.5 and 10 minutes. Flowrates that induce no measurable erosion also are recorded.

\section{Hydrodynamics}

Fully developed turbulent flow exists in the test section for the flow rates of interest. Turbulent flow through pipes has been studied extensively, and empirical functions have been developed which relate the mean flow rate to the wall shear stress. In general, flow in circular cross-section pipes has been investigated. However, the relations developed for flow through circular pipes can be extended to non-circular cross-sections by means of a shape factor. An implicit formula relating the wall shear stress to the mean flow in a pipe of arbitrary cross-section can be obtained from Prandtl's Universal Law of Friction (Schlichting, 1979). For a pipe with a smooth surface, this formula is

$$
\frac{1}{\sqrt{\lambda}}=2.0 \log \left[\frac{U D \sqrt{\lambda}}{v}\right]-0.8
$$

where $U$ is the mean flow speed, $v$ is the kinematic viscosity, $\lambda$ is the friction factor, and $D$ is the hydraulic diameter defined as the ratio of four times the cross-sectional area to the wetted perimeter. For a pipe with a rectangular cross-section, or duct, the hydraulic diameter is

$$
D=2 h w /(h+w)
$$

where $w$ is the duct width and $h$ is the duct height. The friction factor is defined by

$$
\lambda=\frac{8 \tau}{\rho w \mathrm{U}^{2}}
$$


in which $\rho_{w}$ is the density of water and $\tau$ is the wall shear stress. Inserting Equations 2 and 3 into Equation 1 gives the wall shear stress $\tau$ as an implicit function of the mean flow speed U.

For shear stresses in the range of 0.1 to $10.0 \mathrm{~N} / \mathrm{m}^{2}$, the Reynolds numbers, $\mathrm{UD} / \mathrm{v}$, are on the order of $10^{4}$ to $10^{5}$. These values for Reynolds numbers are sufficient for turbulent flow to exist for the stresses of interest in this study. For flow in a circular pipe, turbulent flow theory suggests that the transition from laminar to turbulent flow occurs within 25 to 40 diameters from the entrance to the pipe. Since the hydraulic diameter of the duct pipe is $4 \mathrm{~cm}$, this suggests an entry length of 100 to $160 \mathrm{~cm}$. The length of the duct leading to the test section is $120 \mathrm{~cm}$ and is preceded by a $20-\mathrm{cm}$ flow converter and several meters of inlet pipe. These arguments along with direct observations indicate that the flow is fully turbulent in the test section.

\section{Sediment Erosion Rate Measurements}

This section describes the procedure for measuring sediment erosion rates as a function of applied shear stress and depth below the initial sediment/water interface. Field sediment cores from the Passaic River were obtained as described above and stored in 40-gallon barrels with cool water and ice (replenished daily) until they were eroded.

To measure erosion rates at several different shear stresses using only one core, the following procedure was generally used. Initial tests were run at a low shear stress, and subsequent tests were run at sequentially higher shear stresses with each succeeding shear stress being significantly greater than the previous one. Generally about three shear stresses were run sequentially. At least $0.5 \mathrm{~mm}$ but no more than $2 \mathrm{~cm}$ was eroded for each run of a particular shear stress. The time interval for each run was recorded with a stopwatch. The flow was increased to the next shear stress, and the procedure was repeated until the highest shear stress was run (generally until an erosion rate of 0.033 $\mathrm{cm} / \mathrm{s}$ was measured). This cycle was repeated until all of the sediment had eroded from the core. If a particular shear stress eroded less than $10^{-4} \mathrm{~cm} / \mathrm{s}$ after two cycles, it was dropped from the cycle; if after many cycles the erosion rates decreased significantly, a higher shear stress was included in the cycle. A lower shear stress was sometimes reintroduced to the cycle if it became apparent that a more easily erodable layer was exposed. In general, erosion tests for each cycle were chosen from $0.1,0.2,0.4,0.8,1.6$, 3.2, 4.5, 6.4, 8.0, 10.0, and 12.0 Pascals.

A removable plate above the test section permits access to the core surface and is used to extract samples for bulk property analysis. Bulk property sediment samples were collected after each cycle of erosion tests or at approximately 2 to $3 \mathrm{~cm}$ intervals. These samples were taken from the entire exposed core surface, as there was often heterogeneity across the surface of the core, especially at shallow depths.

Generally, with other bulk properties held constant, erosion rates decrease exponentially as bulk density increases for natural sediments (Jepsen et al. 1997a and 
1997b; Roberts et al. 1998). In general, the data can be approximated by an equation of the form

$$
\begin{array}{ll}
\mathrm{E}=\mathrm{A} \tau^{n} \rho^{m} & \text { For } \tau>\tau_{c r} \\
\mathrm{E}=0 & \text { For } \tau \leq \tau_{c r}
\end{array}
$$

where $\mathrm{E}$ is the erosion rate $(\mathrm{cm} / \mathrm{s}), \tau_{\mathrm{cr}}$ is the critical shear stress for measurable sediment erosion, $\rho$ is the bulk density $\left(\mathrm{g} / \mathrm{cm}^{3}\right)$, and $n, m$, and A are site-specific (or sedimentspecific) constants. It should be noted that in previous studies (Borrowman et al. 2005), change in density with depth is not always the main parameter influencing erosion variability with depth. Variability in organic content or percent fine-grained sediment is sometimes the main factor influencing erosion rate variation with depth. Therefore, organic content or percent fines may be used to replace bulk density in Equation 4. The equations relating sediment erosion to applied shear stress and bulk properties are then used to develop algorithms for predictive models of sediment transport. The constants $n$ and $m$ are determined from erosion experiments on the sediments of interest and will be described in more detail in Chapter 3. Equation 4 has been shown to successfully describe behavior of natural sediments (Jepsen et al. 1997a and 1997b; Jepsen et al. 1998).

Density and other properties do not vary significantly with depth in some natural sediment cores. In these cases, a best-fit curve can be developed between erosion rate and shear stress without using the bulk properties. A simplified version of Equation 4 can be developed that does not include bulk density or other bulk properties by setting $m=0$ in Equation 4:

$$
\begin{array}{ll}
\mathrm{E}=\mathrm{A} \tau^{n} & \text { For } \tau>\tau_{c r} \\
\mathrm{E}=0 & \text { For } \tau \leq \tau_{c r}
\end{array}
$$

\section{Measurements of Sediment Bulk Properties}

Bulk properties were measured at multiple depths in each core by stopping and draining the flume, removing the cover from the test section, and manually extracting a sample of the sediment bed. Measurements included bulk density, grain-size distribution, and organic content of extracted sediment cores determined as a function of depth. These properties may strongly influence erosion; therefore, understanding their variation with depth is an important factor in understanding erosion rate. Since stratigraphy of the sediment is destroyed as the sediments are eroded in Sedflume, samples were extracted from each sediment core during the erosion tests at intervals of approximately 2 to $3 \mathrm{~cm}$. 


\section{Bulk Density Measurements}

To determine the bulk density of the sediments at a particular depth, the weights of the sediment analysis samples, including the cup containing the sample, were measured immediately after extraction from the core. Weight of the cup (tare weight) was measured and recorded prior to sample extraction. Wet weight of the sample was calculated by subtracting tare weight from the weight of the sample. The samples were then dried in the oven at approximately $105 \operatorname{deg} \mathrm{C}$ for 2 days and weighed again (organic material is not incinerated for these calculations). The dry weight of the sample was calculated as the tare weight subtracted from the weight after drying. The water content $W$ is then given

$$
W=\left(\frac{m_{w}-m_{d}}{m_{w}}\right)
$$

where $m_{w}$ and $m_{d}$ are the wet and dry weights, respectively. A volume of sediment, $V$, consists of both solid particles and water and can be written as

$$
V=V_{s}+V_{w}
$$

where $V_{s}$ is the volume of solid particles and $V_{w}$ is the volume of water. If the sediment particles and water have density $\rho_{s}$ and $\rho_{w}$, respectively, the water content of the sediment can be written as

$$
W=\frac{\rho_{w} V_{w}}{\rho V}
$$

where $\rho$ is the bulk density of the sediment sample. A mass balance of the volume of sediment gives

$$
\rho V=\rho_{s} V_{s}+\rho_{w} V_{w}
$$

Equations 5, 6, and 7 are used to derive an explicit expression for the bulk density of the sediment sample, $\rho$, as a function of the water content, $W$, and the densities of the sediment particles and water. This equation is

$$
\rho=\frac{\rho_{\mathrm{s}} \rho_{w}}{\rho_{w}+\left(\rho_{s}-\rho_{w}\right) W}
$$

For the purpose of these calculations, it was assumed that $\rho_{s}=2.65 \mathrm{gm} / \mathrm{cm}^{3}$ and $\rho_{w}=1.05$ $\mathrm{gm} / \mathrm{cm}^{3}$. 


\section{Particle-Size Distribution Measurements}

A Coulter LS Series100 laser particle-sizer was used to measure the particle-size distributions in the subsamples collected from Passaic River Sedflume cores. The LS100 measures particles from $0.4 \mu \mathrm{m}$ to $900 \mu \mathrm{m}$ in size. The particle sizes of Passaic River sediments were measured by pulverizing and sieving sediment samples to remove coarse sand that could damage the Coutler Counter. The passing portion of the sample was added to a small volume of water (about $150 \mathrm{~mL}$ ) and sonicated using a high-powered laboratory sonicator to disperse the sediment. The dispersed solution was placed in the particle-sizer fluid module. The sample is pumped and recirculated through the system, passing the optical module, which is a rigid frame containing light sources, lenses, detectors and printed circuit cards. The optical module includes a spatial filter assembly containing a laser diode and laser beam collimator. The diffraction detector assembly contains a custom photodector array that is used for the measurement of the particle size. The distribution of grain sizes and median grain sizes as a function of depth was obtained from these measurements and scaled according to the weight of sediment retained on the sieve. It should be noted that organic material was not oxidized before grain size analysis was performed; grain size results include organic material.

This report refers to grain-size distribution results in terms of percent clay (the percent passing $6 \mu \mathrm{m}$ ) and percent fines (the percent passing $69 \mu \mathrm{m}$ ). The term "percent clay" is used for convenience to describe the percent passing $6 \mu \mathrm{m}$;, it is not based on any mineralogical analysis.

\section{Organic Content Measurements}

The total organic content (TOC) was measured for each Passaic River sediment core subsample. Samples that had been used to determine bulk density were split and tested for organics, thus ensuring that organic content data could be directly compared to the bulk density data at a given depth. Sediments were dried at $180 \mathrm{deg} C$ and placed in prefired, pre-weighed crucibles. The total weight of the crucible and the dried sediments was recorded. The sediments and crucible were placed in a muffle furnace at $550 \mathrm{deg} \mathrm{C}$ for 30 minutes, removed and allowed to cool in a desiccator. The crucible and sediments were then weighed, and the organic content was calculated as

$$
\operatorname{TOC}(\%)=\left(\frac{m_{d\left(180^{\circ} \mathrm{C}\right)}-m_{d\left(550^{\circ} \mathrm{C}\right)}}{m_{d\left(180^{\circ} \mathrm{C}\right)}}\right)
$$

where $m_{d\left(180^{\circ} \mathrm{C}\right)}$ is the weight of sediments following drying at $180 \mathrm{deg} \mathrm{C}$ and $m_{d\left(550^{\circ} \mathrm{C}\right)}$ is the weight of sediments following drying at $550 \mathrm{deg}$ C. 


\section{Erosion Rate Experiment and Bulk Property Results}

Sedflume experiments were performed on cores from 14 sites along the lower Passaic River, NJ. Two cores were extracted from each site (noted by an 'A' or 'B' on each core ID). Conditions were such that replicate ' $B$ ' cores could not be subcored from a single box core. Replicate cores were therefore anywhere from one to 10 meters apart from one another, which both explains some of the differences in bulk property and erosion rate behavior and illustrates the extent of heterogeneity of Passaic River sediments.

Passaic River sediment cores were often highly stratified. This stratification could sometimes be observed by looking at the core vertical profile through the clear Lexan tube. In addition, testing indicated stratification by discontinuities in bulk property vs. depth profiles and erosion rate vs. depth profiles. The bulk property and erosion rate profiles for the Passaic River Sedflume are discussed in this section for each core. Discontinuities and other significant aspects of the profile are noted. A preliminary analysis of the correlation between bulk property and erosion rate variation is presented for all sediment cores.

\section{Core P01A}

Core P01A was $24.0 \mathrm{~cm}$ long. Dark gray material was present for the top $10 \mathrm{~cm}$ of the core. At $15 \mathrm{~cm}$ depth a black line appeared to separate distinct layers. Small gas pockets were visible intermittently throughout the core. A grayish brown material was intermittently present throughout the core. The core appeared to be fairly homogenous overall.

The bulk density profile for Core P01A (Figure 3) was fairly uniform with depth at about $1.31 \mathrm{~g} / \mathrm{cm}^{3}$. There was a layer of decreased density at $7.5 \mathrm{~cm}$ depth, where the bulk density was $1.21 \mathrm{~g} / \mathrm{cm}^{3}$. The organic content profile (Figure 4) shows an overall decreasing trend with depth. The maximum value was 6.7 percent at $2.9 \mathrm{~cm}$; the minimum organic content was 4.8 percent at a depth of $15.8 \mathrm{~cm}$. The percent fines (silt and clay) decreased steadily with depth from 43.7 percent at $2.9 \mathrm{~cm}$ to 30.9 percent at $7.5 \mathrm{~cm}$ (Figure 5). Percent fines increased to 37.0 percent at $15.8 \mathrm{~cm}$ and decreased to 35.8 percent at $18.9 \mathrm{~cm}$. 
Erosion rates generally decreased with depth (Figure 6), however erosion rates did increase between 9 and $11 \mathrm{~cm}$ depth. The core was much more erosion resistant below $12 \mathrm{~cm}$ depth, where $6.4 \mathrm{~Pa}$ shear stresses induced an erosion rate of about $4 \mathrm{e}-04 \mathrm{~cm} / \mathrm{s}$.

Review of the Sedflume field log book indicated that the increase in erosion rates between 9 and $11 \mathrm{~cm}$ depth was due to a large amount of gas bubbles in that region that caused the sediment core to fracture and fail in large chunks instead of smaller aggregate erosion. The decreasing trend of erosion rate with depth is commonly seen in cohesive sediment cores due to increasing consolidation (bulk density) with depth, and while the increase in density with depth below $7.5 \mathrm{~cm}$ is relatively small, it is the only bulk property that intuitively correlates to the erosion rate response of the core.

\section{Core P01B}

Core P01B was $22.75 \mathrm{~cm}$ long. A $1 \mathrm{~mm}$ black ring was present around the surface of the core. Below the $1 \mathrm{~mm}$ layer a layer of black material mixed with light gray was present for $3.5 \mathrm{~cm}$, and a $4.5 \mathrm{~cm}$ thick layer of light gray material with specks of black lied beneath that. Below the $4.5 \mathrm{~cm}$ thick layer a fairly homogenous, grayish brown material was present for the remainder of the core.

Bulk density (Figure 3) increased with depth from a value of $1.28 \mathrm{~g} / \mathrm{cm}^{3}$ at $1.2 \mathrm{~cm}$ to $1.37 \mathrm{~g} / \mathrm{cm}^{3}$ at $8.2 \mathrm{~cm}$. From $8.2 \mathrm{~cm}$, the bulk density profile shows a decreasing trend with depth, with a density value of $1.26 \mathrm{~g} / \mathrm{cm}^{3}$ at $16.6 \mathrm{~cm}$. Organic content (Figure 4) was found to be 6.4 percent at $1.2 \mathrm{~cm}$ depth. Organic content decreased with depth to 4.0 percent at a depth of $8.2 \mathrm{~cm}$. From that depth, organic content increased steadily with depth to 6.83 percent at $16.6 \mathrm{~cm}$. The percent fines (silt and clay) content (Figure 5) increased with depth from 49.1 percent at $1.2 \mathrm{~cm}$ to 59.4 percent at $4.4 \mathrm{~cm}$. Percent fines decreased to 47.8 percent at $8.2 \mathrm{~cm}$, increased with depth to 53.7 percent at $12.2 \mathrm{~cm}$, and to decreased slightly to 52.9 percent at a depth of $16.6 \mathrm{~cm}$.

Erosion rates generally decreased with depth through the core (Figure 7). A layer of sediments that was highly resistant to erosion was encountered from 6.5 to $9.5 \mathrm{~cm}$ depth. The decreasing erosion rate trend with depth is expected for cohesive sediments. No identifiable trend in any of the sediment bulk properties that rationalizes the decrease in erosion rates. It is possible that some localized variations in bulk properties occurred through this section of the core but were not captured in the bulk property samples that were taken, thus eliminating them as a means of explaining erosional behavior.

\section{Core P02A}

Core $\mathrm{P} 02 \mathrm{~A}$ was $50 \mathrm{~cm}$ long. A $3 \mathrm{~mm}$ black ring was present around the top of the core. The next 10 to $11 \mathrm{~cm}$ of the core was composed of a grayish brown material. 
Below that, there was mostly dark gray material. Many large gas pockets were present throughout the core. A $5 \mathrm{~cm}$ long gas pocket was present at about $19 \mathrm{~cm}$ depth.

Core P02A appears to have been composed of many strata based on Figure 8. Bulk density increased with depth from $1.22 \mathrm{~g} / \mathrm{cm}^{3}$ at $4.8 \mathrm{~cm}$ to $1.31 \mathrm{~g} / \mathrm{cm}^{3}$ at $9.8 \mathrm{~cm}$. Bulk density decreased sharply with depth to $1.24 \mathrm{~g} / \mathrm{cm}^{3}$ at $10.7 \mathrm{~cm}$, increased with depth to $1.32 \mathrm{~g} / \mathrm{cm}^{3}$ at $14.5 \mathrm{~cm}$, decreased to $1.22 \mathrm{~g} / \mathrm{cm}^{3}$ at $19.9 \mathrm{~cm}$, and increased with depth to the highest measured value in the core, $1.4 \mathrm{~g} / \mathrm{cm}^{3}$ at $24.0 \mathrm{~cm}$. Density decreased to $1.27 \mathrm{~g} / \mathrm{cm}^{3}$ at $31.0 \mathrm{~cm}$ and remained fairly constant with depth over the remainder of the core. The organic content profile of P02A also suggests that the core was stratified (Figure 9). Organic content decreased with depth from 8.7 percent at $4.8 \mathrm{~cm}$ to 5.8 percent at $9.8 \mathrm{~cm}$, increased sharply to 6.7 percent at $10.7 \mathrm{~cm}$, and decreased to 5.1 percent at $14.5 \mathrm{~cm}$ depth. Organic content increased significantly to 9.7 percent at $19.9 \mathrm{~cm}$, decreased dramatically to 5.9 percent at $24.0 \mathrm{~cm}$, and increased significantly again to 8.9 percent at $28.2 \mathrm{~cm}$. Organic content decreased to 6.9 percent at $31.0 \mathrm{~cm}$, decreased further to 6.3 percent at $34.9 \mathrm{~cm}$, increased to 7.1 percent at $39.2 \mathrm{~cm}$, and decreased to 6.4 percent at $44.8 \mathrm{~cm}$. The percent fines profile for P02A is shown in Figure 10. Percent fines decreased steadily from 51.1 percent at $4.8 \mathrm{~cm}$ to 40.1 percent at $19.9 \mathrm{~cm}$, and decreased sharply to 13.7 percent at $28.2 \mathrm{~cm}$. Percent fines increased significantly to 64.5 percent at $39.2 \mathrm{~cm}$, and decreased to 51.8 percent at $44.8 \mathrm{~cm}$.

Core P02A showed very erratic erosive behavior and low resistance to erosion (Figure 11). Erosion rates decreased with depth from 9 to $11 \mathrm{~cm}$ depth, and then increased with depth to about $25 \mathrm{~cm}$ depth. Erosion rates then decreased with depth again to about $35 \mathrm{~cm}$ depth. Below that depth an increase in the erosion rates induced by 3.2 and 6.4 Pa shear stresses was observed.

The sharp decrease in erosion rates between 9 and $11 \mathrm{~cm}$ corresponds to a small but marked increase in organic content at that depth. This phenomenon is consistent with previous field observations of decreasing erosion rates resulting from increased organic content (Borrowman et al. 2005). Below $11 \mathrm{~cm}$, the erosion rate behavior of the core seemed to be dictated by the percent fines content of the core. Decreasing percent fines resulted in increased erosion rates to about $25 \mathrm{~cm}$ depth, and increases in percent fines between 25 and $39 \mathrm{~cm}$ depth led to decreasing erosion rates.

\section{Core P02B}

Core P02B was $46.5 \mathrm{~cm}$ long. A mix of light gray, dark gray, and black material made up the top $14 \mathrm{~cm}$ of the core. No plant debris was present at the surface, though some dead animals were. Large gas pockets were present throughout the core.

The bulk density profile for P02A was fairly uniform with only a $0.1 \mathrm{~g} / \mathrm{cm}^{3}$ difference in the maximum value of $1.33 \mathrm{~g} / \mathrm{cm}^{3}$ at $33.8 \mathrm{~cm}$ and the minimum value of $1.22 \mathrm{~g} / \mathrm{cm}^{3}$ at $44.3 \mathrm{~cm}$ (Figure 8). Organic content increased from 6.9 percent at $2.4 \mathrm{~cm}$ depth to 7.8 percent at $5.3 \mathrm{~cm}$, and then decreased to 5.8 percent at $9.4 \mathrm{~cm}$. Organic content remained 
relatively constant from 9.4 to $12.4 \mathrm{~cm}$ and increased to 7.8 percent at a depth of $17.0 \mathrm{~cm}$ (Figure 9). From that depth, organic content decreased steadily to 6.5 percent at $23.3 \mathrm{~cm}$, increased to 7.0 percent at $27.0 \mathrm{~cm}$, decreased to 5.6 percent at $30.6 \mathrm{~cm}$ and to 5.4 percent at $33.8 \mathrm{~cm}$. Organic content increased to 5.6 percent at $40.6 \mathrm{~cm}$ depth and to 7.1 percent at $44.3 \mathrm{~cm}$. Core P02B percent fines profile shows a general increasing trend from 30.9 percent at $2.4 \mathrm{~cm}$ to 38.5 percent at $17.0 \mathrm{~cm}$ (Figure 10). Percent fines decreased sharply to 17.2 percent at $20.1 \mathrm{~cm}$ and increased to 40.9 percent at $23.3 \mathrm{~cm}$. Percent fines remained fairly uniform to $30.6 \mathrm{~cm}$, where it decreased from 40.4 percent to 34.4 percent at $33.8 \mathrm{~cm}$. Percent fines were uniform to $40.6 \mathrm{~cm}$ and decreased to 31.5 percent at $44.3 \mathrm{~cm}$.

Similar to Core P02A, erosion rates for Core P02B were erratic and showed low resistance to erosion (Figure 12). Erosion rate trends for 0.8 and 1.6 Pa were divergent in the top $6.5 \mathrm{~cm}$ of the core. Erosion rates consistently decreased with depth, hitting a relatively resistant layer centered at $14 \mathrm{~cm}$ depth. Erosion rates increased with depth from 14 to $21.3 \mathrm{~cm}$ depth, decreased with depth from 21.3 to $23.3 \mathrm{~cm}$ depth, increased with depth from 23.3 to $32.9 \mathrm{~cm}$ depth, and decreased with depth from that depth to 41.2 cm depth.

The increase in erosion rates for 0.4 and $0.8 \mathrm{~Pa}$ shear stresses around $10 \mathrm{~cm}$ corresponds to a decrease in organic content at position in the core, and the subsequent drop in erosion rates corresponds to a rebound in organic content. The spikes in erosion rate at about 20 and $30 \mathrm{~cm}$ depth in the core correlate to decreases in fines content at those depths, and the decrease in erosion rates around $25 \mathrm{~cm}$ depth correlates to an increase in fines content at that depth. The decrease in erosion rates from 30 to $40 \mathrm{~cm}$ does not readily correlate to any bulk property; as previously mentioned, the descritized bulk property sampling methods used on Sedflume cores may not have captured some bulk property variations that would show an identifiable correlation to erosion rate behavior.

\section{Core P03A}

Core P03A was $47 \mathrm{~cm}$ long, with a surface consisting of a 5-mm deep layer of black material. A $4 \mathrm{~cm}$ layer of grayish-brown material mixed with some black material was underlying the surface and extended to a depth of $4 \mathrm{~cm}$. From 4 to $17 \mathrm{~cm}$, a mix of grayish-brown and dark gray material was present, with darker material more evident with depth. Material was lighter mixed with dark gray between depths of 17 and $24 \mathrm{~cm}$. Below $24 \mathrm{~cm}$, material was light grayish brown. Gas pockets were observed above 24 $\mathrm{cm}$. A dead clam was found on the surface, and the core emitted a sulfurous odor.

The bulk density profile shows an overall increasing trend with depth (Figure 13), though there are an equal number high and low density layers that alternate with depth. The bulk density increased with depth from $1.26 \mathrm{~g} / \mathrm{cm}^{3}$ at $2.2 \mathrm{~cm}$ to $1.4 \mathrm{~g} / \mathrm{cm}^{3}$ at $3.8 \mathrm{~cm}$, decreased to $1.27 \mathrm{~g} / \mathrm{cm}^{3}$ at $6.6 \mathrm{~cm}$, remained nearly constant to $9.2 \mathrm{~cm}$, and then increased with depth to $1.38 \mathrm{~g} / \mathrm{cm}^{3}$ at $15.4 \mathrm{~cm}$. Density decreased with depth to $1.31 \mathrm{~g} / \mathrm{cm}^{3}$ at 
$18.0 \mathrm{~cm}$, increased to $1.48 \mathrm{~g} / \mathrm{cm}^{3}$ at $22.8 \mathrm{~cm}$, decreased to $1.38 \mathrm{~g} / \mathrm{cm}^{3}$ at $25.7 \mathrm{~cm}$, and increased to $1.59 \mathrm{~g} / \mathrm{cm}^{3}$, the maximum value for the core, at $30.8 \mathrm{~cm}$ depth. Bulk density decreased to $1.47 \mathrm{~g} / \mathrm{cm}^{3}$ at $33.2 \mathrm{~cm}$ and to $1.41 \mathrm{~g} / \mathrm{cm}^{3}$ at $37.1 \mathrm{~cm}$, increased to $1.58 \mathrm{~g} / \mathrm{cm}^{3}$ at $40.6 \mathrm{~cm}$, and decreased to $1.51 \mathrm{~g} / \mathrm{cm}^{3}$ at $43.3 \mathrm{~cm}$. The organic content profile of P03A (Figure 14) shows a decreasing tendency with depth with indications of distinct strata at depths that correspond to those observed in the bulk density profile. Organic content decreased from 6.7 percent at $2.2 \mathrm{~cm}$ depth to 5.1 percent at $3.8 \mathrm{~cm}$ depth, increased with depth to 7.4 percent at $6.6 \mathrm{~cm}$ and 8.2 percent at $9.2 \mathrm{~cm}$. Organic content decreased with depth to 6.4 percent at $15.4 \mathrm{~cm}$, increased to 7.0 percent at $18.0 \mathrm{~cm}$, and decreased to 4.4 percent at $22.8 \mathrm{~cm}$. Organic content increased to 6.0 percent at $25.7 \mathrm{~cm}$, decreased to 4.6 percent at $33.2 \mathrm{~cm}$, increased to 5.6 percent at $37.1 \mathrm{~cm}$, decreased to 3.7 percent at $40.6 \mathrm{~cm}$, and increased to 5.0 percent at $43.3 \mathrm{~cm}$. Percent fines in Core P03A decreased from 15.2 percent at $2.2 \mathrm{~cm}$ to 12.9 percent at $3.8 \mathrm{~cm}$, and increased sharply to 33.4 percent at $6.6 \mathrm{~cm}$ (Figure 15). Percent fines decreased to 8.5 percent at $22.8 \mathrm{~cm}$, increased steadily to 18 percent at $33.2 \mathrm{~cm}$, and decreased to 4.6 percent at $43.3 \mathrm{~cm}$.

Core P03A showed a generally increasing resistance to erosion with depth, though two more erodible strata were present in the middle of the core (Figure 16). Erosion rates decreased with depth from the surface to $9.5 \mathrm{~cm}$. A thin layer material with a lower resistance to shear was encountered between 9.5 and $13.1 \mathrm{~cm}$. Erosion rates decreased with depth from 13.1 to $17.8 \mathrm{~cm}$ and increased from 17.8 to $26.7 \mathrm{~cm}$. Erosion rates decreased with depth for the remainder of the core.

The decreasing erosion rate between the surface of the core and the $9.5 \mathrm{~cm}$ depth corresponds to a sharp increase in the percent fines content of the core. Increasing sand content and the failure of the sediment in large chunks due to gas bubbles in that layer rationalize the increased erodibility in the layer between 9.5 and $13.1 \mathrm{~cm}$. The low erosion rates at about $20 \mathrm{~cm}$ depth do not readily correlate to any bulk property measured for Core P03A. There is, however, a spike in fines content at a similar depth in Core P03B. This would rationalize the decreasing erosion rates in Core P03A. It is possible that the resistant layer of material at that depth in Core P03A was so thin that it was eroded before bulk property sampling occurred. The increasing erosion rates between $20 \mathrm{~cm}$ and $27 \mathrm{~cm}$ do not correlate to the bulk sediment properties presented in this report. The field logbook notes increasing amounts of leaves and bubbles in this layer that contributed to the observed increased erodibility. The decreasing erosion rate trend with depth over the remainder of the core is attributed to the increasing bulk density, as organic content was decreasing in this region of the core and sand content was increasing to large values.

\section{Core P03B}

Core P03B was $43.0 \mathrm{~cm}$ long. A $1 \mathrm{~mm}$ black layer was present at the surface. Below that layer, a 0.3 to $1.0 \mathrm{~cm}$ layer of less dark material was present around the core. Beneath that, a mixture of light brown and brownish gray material was present in a $10.5 \mathrm{~cm}$ thick layer. A horizontal black line around half of the core was present at 
$10.5 \mathrm{~cm}$ depth. From $12 \mathrm{~cm}$ depth to the bottom of the core, dark brownish gray sediment, with some black material present at 18 to $23 \mathrm{~cm}$ depth, was present. No gas pockets were visible from outside the core.

Bulk density results suggest that at least four distinct layers existed in Core P03B (Figure 13). Bulk density decreased from $1.37 \mathrm{~g} / \mathrm{cm}^{3}$ at $2.6 \mathrm{~cm}$ to $1.30 \mathrm{~g} / \mathrm{cm}^{3}$ at $5.7 \mathrm{~cm}$. From 5.7 to $12.0 \mathrm{~cm}$, bulk density remained reasonably constant, suggesting possible sediment homogeneity through that section of the core. Bulk density increased with depth to $1.35 \mathrm{~g} / \mathrm{cm}^{3}$ at $5.3 \mathrm{~cm}$, remained relatively constant to $19.3 \mathrm{~cm}$, decreased with depth to $1.30 \mathrm{~g} / \mathrm{cm}^{3}$ at $22.4 \mathrm{~cm}$, increased steadily with depth to $1.5 \mathrm{~g} / \mathrm{cm}^{3}$ at $29.2 \mathrm{~cm}$, and decreased steadily with depth to $1.42 \mathrm{~g} / \mathrm{cm}^{3}$ at $39.9 \mathrm{~cm}$. Organic content decreased slightly from 6.9 percent at $2.6 \mathrm{~cm}$ to 6.7 percent at $5.7 \mathrm{~cm}$ to 6.3 percent at $7.8 \mathrm{~cm}$, then increased with depth to 7.6 percent at $12.0 \mathrm{~cm}$ (Figure 14). Organic content decreased slightly with depth to 7.3 percent at $15.3 \mathrm{~cm}$, decreased to 6.3 percent at $19.3 \mathrm{~cm}$ and remained relatively constant to 6.4 percent at $22.4 \mathrm{~cm}$. Organic content decreased with depth to 4.6 percent at $25.6 \mathrm{~cm}$ and to 4.2 percent at $29.2 \mathrm{~cm}$. Organic content increased steadily with depth to 6.1 percent at $34.2 \mathrm{~cm}$ and increased slightly with depth to 6.4 percent at $39.9 \mathrm{~cm}$. The percent fines content profile for $\mathrm{P} 03 \mathrm{~B}$ showed trends indicative of stratified sediment (Figure 15). Percent fines content increased sharply from 7.6 percent at $2.6 \mathrm{~cm}$ depth to 23.5 percent at $5.7 \mathrm{~cm}$ depth, decreased slightly to 23.3 percent at $7.8 \mathrm{~cm}$ depth, and increased to 28.3 percent at $12.0 \mathrm{~cm}$ depth. Percent fines decreased sharply to $16.7 \mathrm{~cm}$ at $15.3 \mathrm{~cm}$, increased to 18.9 percent at $19.3 \mathrm{~cm}$, and increased more sharply to 29.5 percent at $22.4 \mathrm{~cm}$. Fines content decreased sharply to 14.2 percent at $25.6 \mathrm{~cm}$, remained uniform to $29.2 \mathrm{~cm}$, increased slightly to 16.6 percent at $31.6 \mathrm{~cm}$ depth, decreased to 13.0 percent at $34.2 \mathrm{~cm}$, and increased to 22.9 percent at $39.9 \mathrm{~cm}$.

Core P03B showed a much greater resistance to erosion than P03A (Figure 17). Erosion rates decreased with depth from the surface to $12.3 \mathrm{~cm}$. Erosion rates increased with depth from 12.3 to $23.5 \mathrm{~cm}$, decreased with depth from 23.5 to $32.3 . \mathrm{cm}$. Erosion rates increased with depth from $32.2 \mathrm{~cm}$ to $36.3 \mathrm{~cm}$ and decreased with depth for the remainder of the core.

The increases and decreases in erosion rates with depth for the top $23.5 \mathrm{~cm}$ of the core correlate intuitively to the percent fines content of the core. The decrease in erosion rates between 23.5 and $32.3 \mathrm{~cm}$ correlates to a significant increase in bulk density over that section of the core. The erosion rate results for the remainder of the core appear to correlate with percent fines content.

\section{Core P04A}

Core P04A was $48 \mathrm{~cm}$ long. A 1 to $4 \mathrm{~mm}$ black layer was present at the surface of the core. Beneath that, the next $3.5 \mathrm{~cm}$ of the core was a mixture of brownish gray material with slack spots present consistently throughout. The next $15 \mathrm{~cm}$ beneath that layer was a brown, fairly homogenous material. At the bottom of the brown homogenous layer a crack filled with gas extended around three-fourths of the core. Below the fracture $2 \mathrm{~cm}$ of the same brown homogenous material existed, then a layer consisting of 
a mixture of gray and brown extended to the bottom of the core. Gas pockets were present throughout the core, with two large pockets present at about $27 \mathrm{~cm}$ depth.

The bulk density profile shows high variability with depth, and at least three distinct strata appear in the core (Figue 18). Bulk density decreased significantly with depth from $1.54 \mathrm{~g} / \mathrm{cm}^{3}$ at $3.6 \mathrm{~cm}$ to $1.29 \mathrm{~g} / \mathrm{cm}^{3}$ at $7.2 \mathrm{~cm}$ and to $1.2 \mathrm{~g} / \mathrm{cm}^{3}$ at $10.1 \mathrm{~cm}$. Bulk density increased with depth to $1.28 \mathrm{~g} / \mathrm{cm}^{3}$ at $14.6 \mathrm{~cm}$ and to $1.42 \mathrm{~g} / \mathrm{cm}^{3}$ at $18.4 \mathrm{~cm}$. Density remained fairly constant from $18.4 \mathrm{~cm}$ to $23.2 \mathrm{~cm}$, decreased with depth to $1.29 \mathrm{~g} / \mathrm{cm}^{3}$ at $26.4 \mathrm{~cm}$. Bulk density remained fairly constant from $26.4 \mathrm{~cm}$ to the bottom of the core, varying between $1.29 \mathrm{~g} / \mathrm{cm}^{3}$ and $1.33 \mathrm{~g} / \mathrm{cm}^{3}$. The organic content profile for P04A shows extreme variability with depth and uncommonly high organic contents at three depths in the upper half of the core (Figure 19). The organic content of Core P04A increased from 4.1 percent at $3.55 \mathrm{~cm}$ to 8.2 percent at $7.2 \mathrm{~cm}$, a high organic content relative to most sediments. Organic content continued to increase to 12.3 percent at $10.1 \mathrm{~cm}$, then decreased with depth to 9.5 percent at $14.6 \mathrm{~cm}$ and 5.4 percent at $18.4 \mathrm{~cm}$. Organic content increased with depth to 6.2 percent at $23.2 \mathrm{~cm}$ and 8.2 percent at $26.4 \mathrm{~cm}$, decreased to 7.6 percent at $31.8 \mathrm{~cm}$, increased to 8.7 percent at $36.9 \mathrm{~cm}$, and decreased to 5.7 percent at $42.3 \mathrm{~cm}$. The percent fines content profile for Core P04A shows significant variability in the grain size distribution of the core with depth (Figure 20). Percent fines increased sharply with depth from 2.4 percent at $3.6 \mathrm{~cm}$ to 35.6 percent at $7.2 \mathrm{~cm}$, decreased to 27.5 percent at $10.1 \mathrm{~cm}$ and increased to 32.5 percent at $14.6 \mathrm{~cm}$. Fines decreased sharply to 7.1 percent at $18.4 \mathrm{~cm}$ and increased to 10.4 percent at $18.4 \mathrm{~cm}$. Percent fines increased sharply to 41.3 percent at $26.4 \mathrm{~cm}$, and decreased to 27.0 percent at $42.3 \mathrm{~cm}$.

Erosion rates for Core P04A were erratic (Figure 21). Erosion rates decreased from the surface to $7.3 \mathrm{~cm}$ depth. Erosion increased by multiple orders of magnitude from 7.3 to $11.3 \mathrm{~cm}$ depth and decreased multiple orders of magnitude between 11.3 and $23.5 \mathrm{~cm}$ depth. Erosion rates increased with depth for the remainder of the core below a depth of $23.5 \mathrm{~cm}$. The erosion rate results for Core P04A correlate completely to the percent fines content of the core.

\section{Core P04B}

Core P04B was $44.5 \mathrm{~cm}$ long. A thin dark layer was present at the surface of the core. A floc layer was also present that was greenish brown in color. The top $7.5 \mathrm{~cm}$ of the core was brown with 1 to $2 \mathrm{~mm}$ dark sport. Below that layer, a uniformly colored darker brown material was present to the bottom of the core.

Bulk density decreased with depth from $1.4 \mathrm{~g} / \mathrm{cm}^{3}$ at $2.4 \mathrm{~cm}$ to $1.28 \mathrm{~g} / \mathrm{cm}^{3}$ at $9.6 \mathrm{~cm}$ (Figure 18). Bulk density increased with depth to $1.32 \mathrm{~g} / \mathrm{cm}^{3}$ at $13.4 \mathrm{~cm}$, decreased with depth to $1.28 \mathrm{~g} / \mathrm{cm}^{3}$ at $20.8 \mathrm{~cm}$, increased slightly to $1.31 \mathrm{~g} / \mathrm{cm}^{3}$ at $25.1 \mathrm{~cm}$ depth and remained fairly constant at $1.31 \mathrm{~g} / \mathrm{cm}^{3}$ to $29.0 \mathrm{~cm}$. Bulk density increased notably with depth to $1.42 \mathrm{~g} / \mathrm{cm}^{3}$ at $31.0 \mathrm{~cm}$, and decreased steadily with depth to $1.35 \mathrm{~g} / \mathrm{cm}^{3}$ at $39.9 \mathrm{~cm}$. Substantial variability in the organic content profile for Core P04B can be seen 
in Figure 19. Organic content increased with depth from 3.7 percent at $2.4 \mathrm{~cm} 7$ to 7.5 percent at $9.6 \mathrm{~cm}$, decreased with depth to 5.6 percent at $13.4 \mathrm{~cm}$, and increased with depth to 6.8 percent at $16.6 \mathrm{~cm}$ and 7.2 percent at $20.8 \mathrm{~cm}$. Organic content decreased with depth from $20.8 \mathrm{~cm}$ to a value of 5.5 percent at $25.1 \mathrm{~cm}$, increased to 7.81 percent at $29.0 \mathrm{~cm}$, decreased to 4.9 percent at $31.0 \mathrm{~cm}$, increased to 7.1 percent at $34.9 \mathrm{~cm}$, and decreased to 6.6 percent at $39.9 \mathrm{~cm}$. The percent fines content profile for Core P04B increased steadily with depth over the top third of the core from 5.7 percent at $2.4 \mathrm{~cm}$ to 20.6 percent at $13.4 \mathrm{~cm}$ (Figure 20). Percent fines content decreased significantly to 8.4 percent at $16.6 \mathrm{~cm}$, and increased sharply to 41.4 percent at $20.8 \mathrm{~cm}$. Fines content decreased slightly to 38.9 percent at $25.1 \mathrm{~cm}$, and decreased sharply to 12.3 percent at $31.0 \mathrm{~cm}$. Fines increased steadily to 22.3 percent at $39.9 \mathrm{~cm}$.

Erosion rates generally decreased with depth for the top $14.1 \mathrm{~cm}$ of Core P04B (Figure 22). Erosion rates increased with depth from 14.1 to $18.8 \mathrm{~cm}$ and decreased with depth from 18.8 to $29.1 \mathrm{~cm}$. Erosion rates induced by a $3.2 \mathrm{~Pa}$ shear stress decreased for the remainder of the core; however, increases in erosion rates for the 0.8 and 1.6 Pa shear stresses were observed at about $31 \mathrm{~cm}$.

Similar to Core P04A, the erosion rate results for Core P04B correlate to the percent fines content of the core with one exception; the increase in erosion rates for 0.8 and 1.6 Pa shear stresses appear to correlate to a sudden drop in organic content at that depth.

\section{Core P05A}

Core P05A was $50 \mathrm{~cm}$ long. A black ring surrounded half of the core at the surface. Other than that, the core was fairly homogenous for the top $24 \mathrm{~cm}$ with a neutral gray color. Several gas pockets were present through that layer, and there were black streaks visible for the top $6 \mathrm{~cm}$. Below $24 \mathrm{~cm}$ depth the sediment was a light brown color. This layer contained more gas pockets.

The bulk density profile for Core P05A was fairly uniform for most of the core (Figure 23). The bulk density was $1.4 \mathrm{~g} / \mathrm{cm}^{3}$ at $4.0 \mathrm{~cm}$, below which density decreased with depth to $1.30 \mathrm{~g} / \mathrm{cm}^{3}$ at $8.6 \mathrm{~cm}$. Density remained constant to $12.1 \mathrm{~cm}$, and increased slightly and steadily to $1.32 \mathrm{~g} / \mathrm{cm}^{3}$ at $28.3 \mathrm{~cm}$. Density decreased to $1.31 \mathrm{~g} / \mathrm{cm}^{3}$ at $31.3 \mathrm{~cm}$ depth and remained at that value to $36.0 \mathrm{~cm}$, increased slightly with depth to $1.33 \mathrm{~g} / \mathrm{cm}^{3}$ at $40.2 \mathrm{~cm}$ and decreased to $1.25 \mathrm{~g} / \mathrm{cm}^{3}$ at $44.8 \mathrm{~cm}$. The organic content profile showed some variation between 4.0 and $16.7 \mathrm{~cm}$ and was otherwise relatively uniform (Figure 24). Organic content increased from 5.2 percent at $4.0 \mathrm{~cm}$ to 7.6 percent at $8.6 \mathrm{~cm}$, and decreased steadily to 5.8 percent at $16.7 \mathrm{~cm}$ depth. Organic content varied no more than \pm 0.3 percent from 5.8 for the remainder of the core, with the exception of the lowermost measurement, 6.9 percent at $44.8 \mathrm{~cm}$. The percent fines content profile for Core P05A is given in Figure 25. Percent fines generally increased with depth from 14.8 percent at $4.0 \mathrm{~cm}$ to 59.6 percent at $16.7 \mathrm{~cm}$. Fines decreased sharply to 19.8 percent at $28.2 \mathrm{~cm}$, increased to 30.3 percent at $31.3 \mathrm{~cm}$, and decreased to 28.4 percent at $36.0 \mathrm{~cm}$. Percent fines remained uniform to 40.2 percent, but increased to 58.7 percent at $44.8 \mathrm{~cm}$. 
Core P05A showed an extremely low resistance to erosion (Figure 26). Erosion rates increased with depth from the surface of Core P05A to $9.7 \mathrm{~cm}$ depth. Erosion rates decreased from 9.7 to $13.5 \mathrm{~cm}$ and increased with depth from 13.5 to $27.0 \mathrm{~cm}$. A stratum of more erosion resistant material was encountered between 27.0 and $36.7 \mathrm{~cm}$. The core became increasing erodible with depth below $36.7 \mathrm{~cm}$, showing very little resistance to erosion induced by low shear stresses.

The field logbook indicates that significant organic debris was present in the top $9 \mathrm{~cm}$ of the core, which correlated to the increasing erodibility with depth through that layer of the core. The decrease in erosion rates between 9.7 and $13.5 \mathrm{~cm}$ corresponds to an increase in the percent fines content for that layer of the core. Similarly, the increase in erosion rates from 13.5 to $27.0 \mathrm{~cm}$ depth correlates to a decrease in the percent fines content of the core. The decrease in erosion rates between 27 and $36.7 \mathrm{~cm}$ depth correlates to an increase in both organic and percent fines content; however the decrease in erosion rates seems uncharacteristically large for the relatively small increase in the aforementioned bulk properties. The increase in percent fines content for the remainder of the core would intuitively lead to a decrease in erosion rate, however, as indicated by the field log book, excessive gas content through the bottommost layer of the core caused increased erosion rates.

\section{Core P05B}

Core P05B was $43.5 \mathrm{~cm}$ long. A $2 \mathrm{~mm}$ dark layer was present at the surface of the core with a $3 \mathrm{~mm}$ sandy light brown layer beneath it and a light brown layer below that extended to a depth of $5 \mathrm{~cm}$. Below $5 \mathrm{~cm}$ a light gray layer extended to a depth of $21 \mathrm{~cm}$. Several black spots were present though that layer. From $21 \mathrm{~cm}$ to the bottom of the core, a light gray material mixed with light brown was present. Gas pockets were present throughout this layer.

Bulk density increased with depth from $1.27 \mathrm{~g} / \mathrm{cm}^{3}$ at $3.6 \mathrm{~cm}$ to $1.41 \mathrm{~g} / \mathrm{cm}^{3}$ at $6.6 \mathrm{~cm}$, decreased steadily to $1.29 \mathrm{~g} / \mathrm{cm}^{3}$ at $13.2 \mathrm{~cm}$ and decreased slightly to $1.27 \mathrm{~g} / \mathrm{cm}^{3}$ at $16.5 \mathrm{~cm}$ (Figure 23). Bulk density increased with depth to $1.31 \mathrm{~g} / \mathrm{cm}^{3}$ at $19.9 \mathrm{~cm}$ and to $1.33 \mathrm{~g} / \mathrm{cm}^{3}$ at $29.3 \mathrm{~cm}$, and decreased steadily to $1.28 \mathrm{~g} / \mathrm{cm}^{3}$ at $39.0 \mathrm{~cm}$. The organic content profile appeared to be uniform with two strata of sediment with lower organic contents centered at approximately 6.5 and $26.5 \mathrm{~cm}$ (Figure 24). Organic content decreased with depth from 8.2 percent at $3.6 \mathrm{~cm}$ to 5.6 percent at $6.6 \mathrm{~cm}$, increased with depth to 6.9 percent at $10.2 \mathrm{~cm}$ and 7.3 percent at $13.2 \mathrm{~cm}$. Organic content remained relatively constant from 13.2 percent at $19.9 \mathrm{~cm}$, decreased steadily with depth to 6.1 percent at $30.0 \mathrm{~cm}$ and increased to 8.1 percent at $39.0 \mathrm{~cm}$. The percent fines content profile for Core P05B is shown in Figure 25. Percent fines decreased with depth from 32.9 percent at $3.6 \mathrm{~cm}$ to 15.7 percent at $6.6 \mathrm{~cm}$, increased to 49.3 percent at $16.5 \mathrm{~cm}$, and decreased with depth to 41.7 percent at $25.3 \mathrm{~cm}$. Fines increased to 57.8 percent at 33.6 $\mathrm{cm}$ and decreased to 44.4 percent at $39.0 \mathrm{~cm}$. 
Core P05B was significantly more erosion resistant than Core P05A (Figure 27). Erosion rates induced by 1.6, 3.2, and 6.4 Pa shear stresses generally increased with depth from the surface of the core to $11.4 \mathrm{~cm}$. Erosion rates then generally tended to decrease with depth for the remainder of the core.

The erosion rate results correlate well to the percent fines content of the core. The higher resistance to erosion relative to Core P05A can be attributed to the higher organic content and percent fines content in certain regions of Core P05B.

\section{Core P06A}

Core P06A was $41.0 \mathrm{~cm}$ long. The surface contained leaves and flocculent material, with a dark, $3 \mathrm{~mm}$ ring around the outer edge. The top $15.0 \mathrm{~cm}$ was light gray mixed with black material. The remainder of the core consisted of light grayish material. Gas pockets were observed throughout the core, with many gas pockets visible below $27.0 \mathrm{~cm}$.

Bulk density was uniform in the top $7.5 \mathrm{~cm}$, varying between $1.29 \mathrm{~g} / \mathrm{cm}^{3}$ and $1.31 \mathrm{~g} / \mathrm{cm}^{3}$ (Figure 28). Variation in density was greater below $7.5 \mathrm{~cm}$. Density increased slightly to $1.35 \mathrm{~g} / \mathrm{cm}^{3}$ at $11.0 \mathrm{~cm}$, but decreased to 1.21 at $14.2 \mathrm{~cm}$. Density increased to $1.33 \mathrm{~g} / \mathrm{cm}^{3}$ at $16.9 \mathrm{~cm}$, decreased steadily to $1.19 \mathrm{~g} / \mathrm{cm}^{3}$ at $23.0 \mathrm{~cm}$, below which density increased to $1.39 \mathrm{~g} / \mathrm{cm}^{3}$ at the lowest sample location of $36.6 \mathrm{~cm}$. Organic content (Figure 29) increased slightly from 5.9 percent at $2.8 \mathrm{~cm}$ to 6.3 percent at $7.9 \mathrm{~cm}$. The profile mirrors that of the bulk density profile below $7.9 \mathrm{~cm}$; variation in organic content corresponds inversely to variations in bulk density. Organic content decreased to 6.5 percent at $11.0 \mathrm{~cm}$, increased to 13.0 percent at $14.2 \mathrm{~cm}$, decreased to 6.9 percent at $16.9 \mathrm{~cm}$, increased slightly to 7.4 percent at 20.0 and increased to 12.1 percent at $23.0 \mathrm{~cm}$, and decreased to 6.2 percent at $36.6 \mathrm{~cm}$. Figure 30 shows that material generally became finer with depth to $20 \mathrm{~cm}$, but included two strata of coarser material. Percent fines increased from 17.9 percent at $2.8 \mathrm{~cm}$ to 27.5 percent at $7.5 \mathrm{~cm}$. Fines dropped to 23.2 percent at $11.0 \mathrm{~cm}$, but increased to 33.2 percent at $14.2 \mathrm{~cm}$. Percent fines decreased to 20.4 percent at $16.9 \mathrm{~cm}$ and increased to 39.1 percent at $20.0 \mathrm{~cm}$. Fines decreased to 25.7 percent at $23.0 \mathrm{~cm}$, decreased slightly to 24.5 percent at $28.1 \mathrm{~cm}$, increased sharply to 31.8 percent at $33.4 \mathrm{~cm}$, and decreased to 27.4 percent at $36.6 \mathrm{~cm}$.

Erosion rates decreased with depth in the top $5 \mathrm{~cm}$ of core P06A (Figure 31). Sediment was only eroded by a $1.6 \mathrm{~Pa}$ shear stress between 5 and $14 \mathrm{~cm}$, which can be attributed to a spike in organic content. Erosion rates generally increased with depth from $14 \mathrm{~cm}$ to $24 \mathrm{~cm}$. The field log noted that gas bubbles escaping caused much of the erosion in this section of the core. Also noted in the log book was that leaves between 24 and $27 \mathrm{~cm}$ protected the sediment surface from the flow, causing erosion rates to decrease. Erosion increased between 27 and $29 \mathrm{~cm}$.

\section{Core P06B}

Core P06B was $46.5 \mathrm{~cm}$ long, with a 5-mm wide black ring around the edge. The surface contained light gray material and progressively became darker with depth through 
the top $10 \mathrm{~cm}$ of the core. The top $10 \mathrm{~cm}$ contained dark spots of black material. Between 10 and $24 \mathrm{~cm}$, material was a darker gray mixed with black material, with less black material present with depth. The remainder of the core was dark gray material with occasional spots of black material. A few gas pockets were present through out the core.

Bulk density increased slightly from $1.26 \mathrm{~g} / \mathrm{cm}^{3}$ at $2.75 \mathrm{~cm}$ to $1.29 \mathrm{~g} / \mathrm{cm}^{3}$ at $6.4 \mathrm{~cm}$ and further to $1.33 \mathrm{~g} / \mathrm{cm}^{3}$ at $8.9 \mathrm{~cm}$ (Figure 28). Below $8.9 \mathrm{~cm}$, density oscillated, decreasing to $1.26 \mathrm{~g} / \mathrm{cm}^{3}$ at $13.2 \mathrm{~cm}$. Density steadily increased to $1.34 \mathrm{~g} / \mathrm{cm}^{3}$ at 19.10 $\mathrm{cm}$, decreased to $1.22 \mathrm{~g} / \mathrm{cm}^{3}$ at $21.75 \mathrm{~cm}$, increased to $1.31 \mathrm{~g} / \mathrm{cm}^{3}$ at 27.35 , decreased slightly to $1.27 \mathrm{~g} / \mathrm{cm}^{3}$ at $37.15 \mathrm{~cm}$, and increased to $1.32 \mathrm{~g} / \mathrm{cm}^{3}$ at $41.2 \mathrm{~cm}$. Organic content decreased slightly from 7.5 percent at $2.8 \mathrm{~cm}$ to 7.3 percent at $8.9 \mathrm{~cm}$ and decreases more sharply to 6.1 percent at $13.2 \mathrm{~cm}$ (Figure 29). An increase in organic content is observed between $13.2 \mathrm{~cm}$ and $21.8 \mathrm{~cm}$; a slight increase between 13.2 and $19.1 \mathrm{~cm}$ to 7.7 percent, but more significantly to 11.5 percent between $19.1 \mathrm{~cm}$ at 21.8 $\mathrm{cm}$. Organic content decreases to 7.5 percent at $27.4 \mathrm{~cm}$, increases to 11.7 percent at $37.2 \mathrm{~cm}$, and decreases to 9.4 percent at the lowest sample point of $41.2 \mathrm{~cm}$. The profile mirrors the bulk density profile, below $19.1 \mathrm{~cm}$, particularly at $21.8 \mathrm{~cm}$ where a significant increase in organic content corresponds to a sharp decrease in bulk density. Percent fines increased from 33.3 percent at $2.75 \mathrm{~cm}$ to 36.1 percent at $6.4 \mathrm{~cm}$ and decreased to 22.9 percent at $8.9 \mathrm{~cm}$ (Figure 30). Fines increased sharply to 55.3 percent at $13.2 \mathrm{~cm}$. The material was generally coarser with depth between 13.2 and $37.2 \mathrm{~cm}$. Percent fines decreased to 28.8 percent at $19.1 \mathrm{~cm}$, increased to 36.2 percent at $21.8 \mathrm{~cm}$, and decreased to 20.0 percent at $37.2 \mathrm{~cm}$. Fines increased to 47.2 percent at the lowest sample point at $41.2 \mathrm{~cm}$.

Core P06B was more resistant to erosion than Core P06A, and higher shear stresses were applied (Figure 32). Although bulk densities were similar between the cores, Core $\mathrm{P} 06 \mathrm{~B}$ contained higher percent fines content in the top $30 \mathrm{~cm}$. Erosion generally decreased with depth in the top $19 \mathrm{~cm}$ of the core. Erosion rates increased between 19 and $29 \mathrm{~cm}$, where it was observed from the logbook that many leaves were mixed with sediment. Additionally, erosion caused by gas bubbles was noted at approximately the $27 \mathrm{~cm}$ depth. Erosion decreased at $33 \mathrm{~cm}$ and increased slightly at $40 \mathrm{~cm}$.

\section{Core P07A}

Core P07A was $40.0 \mathrm{~cm}$ long, with a $1-\mathrm{cm}$ wide dark ring around the surface and twigs on the surface. Black and gray material were mixed in the top $10 \mathrm{~cm}$ of the core. A large gas pocket was located $9 \mathrm{~cm}$ deep. Material was fairly homogeneous below $10 \mathrm{~cm}$, with a few gas pockets between 10 and $20 \mathrm{~cm}$ depths. Several large gas pockets were visible below $20 \mathrm{~cm}$, ranging between 1 to $3 \mathrm{~cm}$ in length and 0.5 to $3 \mathrm{~cm}$ in width.

Bulk density decreased slightly from $1.20 \mathrm{~g} / \mathrm{cm}^{3}$ to $1.18 \mathrm{~g} / \mathrm{cm}^{3}$ between depths of $4.7 \mathrm{~cm}$ and $8.8 \mathrm{~cm}$ (Figure 33). Density increased to $1.30 \mathrm{~g} / \mathrm{cm}^{3}$ at $15.7 \mathrm{~cm}$ depth, decreased slightly to $1.28 \mathrm{~g} / \mathrm{cm}^{3}$ at $18.6 \mathrm{~cm}$ depth, and increased to $1.30 \mathrm{~g} / \mathrm{cm}^{3}$ at $24.9 \mathrm{~cm}$. Density decreased to $1.17 \mathrm{~g} / \mathrm{cm}^{3}$ at $28.7 \mathrm{~cm}$, increased to $1.23 \mathrm{~g} / \mathrm{cm}^{3}$ at $31.9 \mathrm{~cm}$, and decreased to $1.16 \mathrm{~g} / \mathrm{cm}^{3}$ at the lowest sample point of $36.6 \mathrm{~cm}$. Organic content displayed 
a decreasing trend from 9.9 percent at $4.7 \mathrm{~cm}$ depth to 6.1 percent at $15.7 \mathrm{~cm}$ (Figure 34). Organic content increased to 8.5 percent at $18.6 \mathrm{~cm}$ and decreased to 5.9 percent at $24.9 \mathrm{~cm}$. Below $24.9 \mathrm{~cm}$, organic content increased to the bottom of the core to 15.5 percent. Percent fines increased from 15.5 percent at $4.7 \mathrm{~cm}$ to 25.8 percent at $11.5 \mathrm{~cm}$ (Figure 35). Percent fines decreased to 14.6 percent at $18.6 \mathrm{~cm}$, increased to 27.4 percent at $24.9 \mathrm{~cm}$, and decreased to 22.0 percent at $28.7 \mathrm{~cm}$. Fines were uniform below $28.7 \mathrm{~cm}$; 23.6 percent at $31.9 \mathrm{~cm}$ and 22.1 percent at $36.6 \mathrm{~cm}$.

Erosion rates of Core P07A (Figure 36) were influenced by the presence of leaves and trapped gas. The logbook notes that emerging gas bubbles caused much of erosion in the upper $7 \mathrm{~cm}$ of the core. P07A. Between 7 and $10 \mathrm{~cm}$ and 14 and $16 \mathrm{~cm}$, leaves obstructed the flow from the sediment surface and rates decreased. Erosion rates increased between 10 and $14 \mathrm{~cm}$ and between 16 and $28 \mathrm{~cm}$, where organic content decreased. Erosion rates increased below $28 \mathrm{~cm}$, where the logbook notes gas bubbles were present.

\section{Core P07B}

Core P07B was $39.0 \mathrm{~cm}$ long and leaves were visible throughout the core. A $1 \mathrm{~cm}$ ring of black material was present on the outer portion of the surface. A mixed layer of light brown, dark gray, and black material was present with gas pockets between 1 and $9 \mathrm{~cm}$ depths. Dark gray material was present between 9 and $20 \mathrm{~cm}$ depth, below which was a $6 \mathrm{~cm}$ pocket of leaves mixed with sediment between 21 and $27 \mathrm{~cm}$. The layer contained horizontal fractures. Lighter gray material was present from $27 \mathrm{~cm}$ to the bottom of the core, which contained many fractures. Many gas pockets were observed throughout the core.

Bulk density was fairly constant between $2.9 \mathrm{~cm}$ and $6.8 \mathrm{~cm}$ depth, increasing from $1.21 \mathrm{~g} / \mathrm{cm}^{3}$ to $1.22 \mathrm{~g} / \mathrm{cm}^{3}$, respectively (Figure 33). Density increased sharply to $1.44 \mathrm{~g} / \mathrm{cm}^{3}$ at a depth of $12.1 \mathrm{~cm}$, and decreased to $1.20 \mathrm{~g} / \mathrm{cm}^{3}$ at $17.6 \mathrm{~cm}$. Density increased sharply to $1.42 \mathrm{~g} / \mathrm{cm}^{3}$ at $27.1 \mathrm{~cm}$ and steadily increased to $1.51 \mathrm{~g} / \mathrm{cm}^{3}$ at the last sample location of $35.5 \mathrm{~cm}$. Organic content decreases from 10.5 percent at a depth of $2.9 \mathrm{~cm}$ to 5.6 percent at $12.1 \mathrm{~cm}$, and a slight organic content increase to 6.2 percent occurs at $14.8 \mathrm{~cm}$ (Figure 34). A sharp increase in organic content to 10.6 percent is observed at $17.6 \mathrm{~cm}$. Organic content decreases below this point to 5.6 percent at $27.1 \mathrm{~cm}$. Organic content steadily increases to 6.7 percent at $34.0 \mathrm{~cm}$ and drops to 5.8 percent at $35.5 \mathrm{~cm}$. Percent fines increased from 23.2 percent at $2.9 \mathrm{~cm}$ to 26.9 percent at $6.8 \mathrm{~cm}$ (Figure 35). The material became increasingly sandier with depth below $6.8 \mathrm{~cm}$. Fines decreased to 14.7 percent at $17.6 \mathrm{~cm}$, increased to 21.2 percent at $24.1 \mathrm{~cm}$, decreased to 4.9 percent at $34.0 \mathrm{~cm}$, and increased slightly to 7.7 percent at $35.5 \mathrm{~cm}$.

Higher shear stresses were applied with core P07B than core P07A indicating more resistant material (Figure 37). Erosion of the core appears to be influenced by the bulk properties, particularly the organic content. Erosion rates generally increased with depth to $14 \mathrm{~cm}$ where organic content decrease. Organic content increases between 14 and $19 \mathrm{~cm}$ and erosion rates decrease. From the logbook, it is noted a leaf layer was present between 19 and $25 \mathrm{~cm}$, and no erosion occurred. At $25 \mathrm{~cm}$, erosion increased and the 
logbook notes a sandy layer. Erosion rates decreased between 25 and $35 \mathrm{~cm}$. Although sand was present, the logbook indicates that the material in this section was very cohesive. Erosion between 25 and $35 \mathrm{~cm}$ appears to be a function of an increase in density.

\section{Core P08A}

Core P08A was $34.5 \mathrm{~cm}$ long with a 2-mm wide black ring around the surface. The top 1.0 to $2.5 \mathrm{~cm}$ of the core consisted of a light brown material mixed with black material. The remainder of the core was a darker brown material mixed with some black material. Gas pockets, approximately $1 \mathrm{~cm}$ in diameter, were visible throughout the core.

Bulk density increases from $1.32 \mathrm{~g} / \mathrm{cm}^{3}$ at $4.0 \mathrm{~cm}$ to $1.36 \mathrm{~g} / \mathrm{cm}^{3}$ at $7.1 \mathrm{~cm}$ (Figure 38). Density decreased to $1.29 \mathrm{~g} / \mathrm{cm}^{3}$ at $9.8 \mathrm{~cm}$ depth and was fairly uniform to a depth of $25.6 \mathrm{~cm}$; density varied from $1.28 \mathrm{~g} / \mathrm{cm}^{3}$ to $1.30 \mathrm{~g} / \mathrm{cm}^{3}$. Density decreased slightly to $1.24 \mathrm{~g} / \mathrm{cm}^{3}$ at $31.0 \mathrm{~cm}$, the lowest sample location. Organic content increases from 6.8 percent at $4.0 \mathrm{~cm}$ deep to 8.4 percent at a depth of $9.8 \mathrm{~cm}$ depth (Figure 39). Organic content decreased to 7.3 percent at a depth of $15.0 \mathrm{~cm}$ and increased to 8.3 percent at $18.0 \mathrm{~cm}$. Density decreased slightly to 8.1 percent at $21.9 \mathrm{~cm}$, increased slightly to 8.3 percent, and sharply increased to 13.3 percent at $31.0 \mathrm{~cm}$. Percent fines increased from 27.4 percent at $4.0 \mathrm{~cm}$ to 48.2 percent at $9.9 \mathrm{~cm}$, decreased to 39.2 percent at $15.0 \mathrm{~cm}$, increased slightly to 41.9 percent at $18.1 \mathrm{~cm}$, decreased to 34.8 percent at $21.9 \mathrm{~cm}$, increased to 44.9 percent at $25.6 \mathrm{~cm}$, and increased to 47.99 percent at $31.0 \mathrm{~cm}$ (Figure 40).

Core P08A erosion rates generally decreased with depth in the upper $15 \mathrm{~cm}$, except rates applied with a 1.6 Pa shear stress, which was uniform between 6 and $15 \mathrm{~cm}$ (Figure 41). The decrease in erosion rates correlates with an increase in percent fines (density and organic content were uniform). The logbook indicates emerging gas bubbles were associated with erosion with the 1.6 Pa shear stress. Emerging gas also was present between 16 and $19 \mathrm{~cm}$ and between 26 and $29 \mathrm{~cm}$, where erosion rates were observed to increase.

\section{Core P08B}

Core P08B was $33.0 \mathrm{~cm}$ in length. The top $9 \mathrm{~cm}$ contained light brown material with occasional traces of dark material. The remainder of the core consisted of dark grayish sediment. Gas pockets were visible throughout the core, including a $2 \mathrm{~cm}$ long pocket $18 \mathrm{~cm}$ deep.

Bulk density was consistent throughout most of the core; density was $1.24 \mathrm{~g} / \mathrm{cm}^{3}$ between depths of 3.0 and $5.8 \mathrm{~cm}$, increased slightly to $1.28 \mathrm{~g} / \mathrm{cm}^{3}$ at $13.8 \mathrm{~cm}$ depth and remained a constant density to a depth of $24.8 \mathrm{~cm}$ (Figure 38). Density increased to $1.5 \mathrm{~g} / \mathrm{cm}^{3}$ at $29.0 \mathrm{~cm}$. Organic content was highest at the uppermost sampling point, 9.9 
percent at $3.0 \mathrm{~cm}$ depth (Figure 39). Organic content decreased to 6.1 percent at $9.8 \mathrm{~cm}$ depth, increased slightly to 7.0 percent at $13.8 \mathrm{~cm}$, decreased to 5.8 percent at $17.7 \mathrm{~cm}$, and increased to 7.3 percent at $22.2 \mathrm{~cm}$. Organic content decreased slightly to 7.2 percent at $24.8 \mathrm{~cm}$ and decreased more sharply to 4.2 percent at $29.0 \mathrm{~cm}$. Percent fines increased slightly from 33.0 percent at $3.0 \mathrm{~cm}$ to 35.8 percent at $5.8 \mathrm{~cm}$ and decreased to 31.7 percent at $9.8 \mathrm{~cm}$ (Figure 40). Fines increased sharply at $13.8 \mathrm{~cm}$ to 51.7 percent, decreased to 36.7 percent at $17.7 \mathrm{~cm}$, increased to 49.2 percent at $22.2 \mathrm{~cm}$, and decreased to 10.2 percent at $29.0 \mathrm{~cm}$.

Erosion of Core P08B is associated with percent fines. Erosion rates decreased with depth in the top $14 \mathrm{~cm}$ of the core (Figure 42), which corresponds with an increasing trend in percent fines. Erosion increased between 14 and $19 \mathrm{~cm}$ where percent fines decreased, and decreased between 19 and $23 \mathrm{~cm}$ with an increase in percent fines. The core became sandier below $23 \mathrm{~cm}$, and erosion rates increased. It should be noted from the logbook that most of the runs on this core had gas bubbles present.

\section{Core P09A}

Core P09A was $65.5 \mathrm{~cm}$ long. Gas bubbles were present throughout the core, but contained mainly in the upper two-thirds of the core. Additionally, the bubbles present in the lower third of the core were observed to be smaller than the upper portion of the core. The outer portion of the surface contained a $1 \mathrm{~mm}$ ring of black material. The core consisted of mostly brown material; however the upper $7 \mathrm{~cm}$ contained brown material mixed with gray material.

The bulk density profile for core P09A (Figure 43) shows a generally consistent density throughout the core. Density decreased from $1.24 \mathrm{~g} / \mathrm{cm}^{3}$ at $2.1 \mathrm{~cm}$ depth to $1.22 \mathrm{~g} / \mathrm{cm}^{3}$ at $5.1 \mathrm{~cm}$ depth, and remained constant to $7.6 \mathrm{~cm}$. Density increased slightly to $1.25 \mathrm{~g} / \mathrm{cm}^{3}$ at $11.4 \mathrm{~cm}$, decreased slightly to $1.24 \mathrm{~g} / \mathrm{cm}^{3}$ at $14.8 \mathrm{~cm}$, and increased to $1.28 \mathrm{~g} / \mathrm{cm}^{3}$ at $20.0 \mathrm{~cm}$. Density decreased to $1.25 \mathrm{~g} / \mathrm{cm}^{3}$ at $24.4 \mathrm{~cm}$, increased slightly to $1.26 \mathrm{~g} / \mathrm{cm}^{3}$ at $27.9 \mathrm{~cm}$, and remained constant to the lowest sampling point at $31.4 \mathrm{~cm}$. Organic content increased from 7.2 percent at $2.1 \mathrm{~cm}$ to 8.8 percent at $5.1 \mathrm{~cm}$ and decreased slightly to 8.7 percent at $7.6 \mathrm{~cm}$ (Figure 44). Organics decreased further to 6.4 percent at $11.4 \mathrm{~cm}$, increased to 7.4 percent at $14.8 \mathrm{~cm}$, and decreased to 6.9 percent at $20.0 \mathrm{~cm}$. Organic content increased to 7.7 percent at $24.4 \mathrm{~cm}$, increased slightly to 7.9 percent at $27.9 \mathrm{~cm}$ and decreased to 7.4 percent at $31.4 \mathrm{~cm}$. Percent fines (Figure 45) increased from 30.6 percent at $2.1 \mathrm{~cm}$ to 38.6 percent at $5.1 \mathrm{~cm}$, decreased to 20.5 percent at $7.6 \mathrm{~cm}$, and was uniform to $11.4 \mathrm{~cm}$ (20.8 percent). Material became generally finer with depth to $24.4 \mathrm{~cm}$; percent fines increased to 29.7 percent at $14.8 \mathrm{~cm}$, decreased to 24.4 percent at $20.0 \mathrm{~cm}$, and increased to 36.8 percent at $24.4 \mathrm{~cm}$. Fines decreased to 32.0 percent at $27.9 \mathrm{~cm}$, was uniform to $31.4 \mathrm{~cm}$, decreased to 25.6 percent at $35.5 \mathrm{~cm}$, and increased significantly to 58.5 percent at $43.1 \mathrm{~cm}$.

In general, Core P09A erosion rates increased in the top $10 \mathrm{~cm}$ of the core (Figure 46), which corresponds to a decrease in percent fines. The varying erosion rates 
throughout most of the remainder of the core do not appear to relate to bulk properties. The logbook states that erosion caused by emerging gas bubbles occurred during many runs.

\section{Core P09B}

Core P09B was $45.2 \mathrm{~cm}$ in length. The top $1 \mathrm{~cm}$ consisted of dark brown material with a $1 \mathrm{~mm}$ dark ring at the surface. A 4-cm deep layer of light brown material was present below the upper layer and contained gas pockets and fractures. The remainder of the core consisted of a brownish gray material with many gas pockets.

Bulk density increased from $1.23 \mathrm{~g} / \mathrm{cm}^{3}$ at a depth of $4.4 \mathrm{~cm}$ to $1.30 \mathrm{~g} / \mathrm{cm}^{3}$ at $12.2 \mathrm{~cm}$, decreased to $1.21 \mathrm{~g} / \mathrm{cm}^{3}$ at $16.8 \mathrm{~cm}$, and decreased slightly to $1.19 \mathrm{~g} / \mathrm{cm}^{3}$ at $21.4 \mathrm{~cm}$ (Figure 43). Bulk density remained $1.19 \mathrm{~g} / \mathrm{cm}^{3}$ to $27.6 \mathrm{~cm}$, increased to $1.26 \mathrm{~g} / \mathrm{cm}^{3}$ at $37.6 \mathrm{~cm}$, and decreased slightly to $1.25 \mathrm{~g} / \mathrm{cm}^{3}$ at $40 \mathrm{~cm}$. Organic content decreased slightly from 9.7 percent at $4.4 \mathrm{~cm}$ depth to 9.3 percent at $9.4 \mathrm{~cm}$ depth (Figure 44) . Organic content dropped to 6.5 percent at $12.2 \mathrm{~cm}$, increased sharply to 12.6 percent at $21.4 \mathrm{~cm}$. Organics decreased steadily to 9.2 percent at $37.6 \mathrm{~cm}$ and increased to 9.9 percent at $40.0 \mathrm{~cm}$. Percent fines (Figure 45) decreased from 46.1 percent at $4.4 \mathrm{~cm}$ to 31.3 percent at $12.2 \mathrm{~cm}$, increased to 42.1 percent at $21.4 \mathrm{~cm}$, decreased to 28.1 percent at $27.6 \mathrm{~cm}$, increased to 46.2 percent at $37.6 \mathrm{~cm}$, and decreased slightly to 44.3 percent at $40.0 \mathrm{~cm}$.

Core P09B erosion rates decreased in the upper $12 \mathrm{~cm}$, and increased between 12 and $31 \mathrm{~cm}$ (Figure 47). Erosion rates generally decreased between 31 and $39 \mathrm{~cm}$. Erosion rates appear to follow the bulk density trend.

\section{Core P11A}

Core $11 \mathrm{~A}$ was $42.5 \mathrm{~cm}$ long. A $1 \mathrm{~mm}$ black layer was present at the surface. The top $2.5 \mathrm{~cm}$ of the core was mostly black material with some light brown sporadically mixed in. On one side of the core, a light brown layer was present from 2.5 to $19 \mathrm{~cm}$ depth, below which the light brown transitions to gray. On the other side of the core, the same trend was observed however the light brown transitioned to gray at $7 \mathrm{~cm}$ depth. Several gas pockets were present throughout the core.

The bulk density profile of Core P11A is shown in Figure 48. Density decreased with depth from $1.3 \mathrm{~g} / \mathrm{cm}^{3}$ at $2.3 \mathrm{~cm}$ to $1.26 \mathrm{~g} / \mathrm{cm}^{3}$ at $8.7 \mathrm{~cm}$, decreased more abruptly with depth to $1.23 \mathrm{~g} / \mathrm{cm}^{3}$ at $9.6 \mathrm{~cm}$, increased to $1.34 \mathrm{~g} / \mathrm{cm}^{3}$ at $15.2 \mathrm{~cm}$, and decreased steadily to $1.25 \mathrm{~g} / \mathrm{cm}^{3}$ at $25.8 \mathrm{~cm}$. Bulk density increased to $1.29 \mathrm{~g} / \mathrm{cm}^{3}$ at $29.8 \mathrm{~cm}, 1.34 \mathrm{~g} / \mathrm{cm}^{3}$ at $32.7 \mathrm{~cm}$, and decreased to $1.33 \mathrm{~g} / \mathrm{cm}^{3}$ at $38.3 \mathrm{~cm}$. The organic content profile for Core P11A is given in Figure 49. Organic content increased very slightly with depth from 6.4 percent at $2.3 \mathrm{~cm}$ to 7.1 percent at $9.6 \mathrm{~cm}$, decreased to 5.2 percent at $15.2 \mathrm{~cm}$, increased to 7.6 percent at $22.0 \mathrm{~cm}$, increased slightly to 7.8 percent at $25.8 \mathrm{~cm}$, decreased to 6.9 percent at $32.7 \mathrm{~cm}$, and remained relatively constant to the bottom of the core at $38.3 \mathrm{~cm}$. The percent fines content profile for Core P11A is indicative of a highly 
stratified core (Figure 50). It appears that at least five grain-size strata were present in the core. The percent fines decreased with depth from 25.5 percent at $2.3 \mathrm{~cm}$ to 18.1 percent at $5.75 \mathrm{~cm}$, increased slightly to 21.0 percent at $8.7 \mathrm{~cm}$, and increased significantly to 33.6 percent at $9.6 \mathrm{~cm}$. The percent fines content decreased with depth significantly to 12.8 percent at $22.0 \mathrm{~cm}$, abruptly increased to 33.1 percent at $25.8 \mathrm{~cm}$, decreased to 17.2 percent at $32.7 \mathrm{~cm}$, and increased to 36.9 percent at $38.3 \mathrm{~cm}$.

Core P11A was very sandy and therefore, as expected, has an extreme lack of resistance to erosion. Erosion rates decreased with depth in the upper $10 \mathrm{~cm}$ of the core, with a layer where no measurable erosion was present at a 1.6 Pa shear stress (Figure 51). Erosion rates increased with depth from $11 \mathrm{~cm}$ to about the $19 \mathrm{~cm}$. Erosion rates for the 0.4 and $0.8 \mathrm{~Pa}$ shear stresses decreased at about $22 \mathrm{~cm}$. Erosion rates for both the $0.8 \mathrm{~Pa}$ and 1.6 Pa shear stresses decreased with depth from about $25 \mathrm{~cm}$ to the bottom of the core.

The decreasing erosion rates in the top $10 \mathrm{~cm}$ of the core correlate to an increase in organic content in that region of the core; however the total increase in organic content is less than one percent. The increase in erosion rates from 11 to $19 \mathrm{~cm}$ correlates to decreasing percent fines content through that region of the core. The decrease in erosion for the 0.4 and $0.8 \mathrm{~Pa}$ shear stresses corresponds to an increase in organic content in that layer. The decreasing erosion rates from 25 to $32 \mathrm{~cm}$ correlate only to increasing bulk density in that region, apparently showing that density effects are more pronounced in the gray material comprising the lower layer of the core.

\section{Core P11B}

Core P11B was $51.1 \mathrm{~cm}$ long. A $1 \mathrm{~mm}$ black layer was present at the surface of the core. A $2.5 \mathrm{~cm}$ thick layer consisting of a mixture of black and brown material was present at the top of the core. Below that layer was a layer of brown material that varied in thickness from 1 to $4 \mathrm{~cm}$. A grayish brown material was present below that layer to 28 $\mathrm{cm}$ depth. Beneath the grayish brown layer a brown material with some black mixed in was present. Several gas pockets were visible in the core, with a majority of them residing below $23 \mathrm{~cm}$ depth.

The bulk density profile for Core P11B closely followed that of Core P11A (Figure 48). Bulk density increased steadily with depth from $1.23 \mathrm{~g} / \mathrm{cm}^{3}$ at $3.3 \mathrm{~cm}$ to $1.31 \mathrm{~g} / \mathrm{cm}^{3}$ at $15.3 \mathrm{~cm}$, decreased to $1.22 \mathrm{~g} / \mathrm{cm}^{3}$ at $25.1 \mathrm{~cm}$, and increased to $1.33 \mathrm{~g} / \mathrm{cm}^{3}$ at $30.5 \mathrm{~cm}$. The bulk density profile is somewhat erratic below $30.5 \mathrm{~cm}$, with values of $1.29 \mathrm{~g} / \mathrm{cm}^{3}$ at $34.3 \mathrm{~cm}, 1.38 \mathrm{~g} / \mathrm{cm}^{3}$ at $37.0 \mathrm{~cm}$, and $1.34 \mathrm{~g} / \mathrm{cm}^{3}$ at $40.8 \mathrm{~cm}$. The organic content profile for Core P11B shows higher organic content readings for the upper $30.5 \mathrm{~cm}$ of the core (Figure 49). Organic content increased with depth from 7.7 percent at $3.3 \mathrm{~cm}$ to 8.91 percent at $11.2 \mathrm{~cm}$, decreased with depth to 8.3 percent at $19.5 \mathrm{~cm}$, and increased significantly to 11.5 percent at $25.1 \mathrm{~cm}$. Organic content decreased significantly to 7.6 percent at $30.5 \mathrm{~cm}$, increased with depth to 7.9 percent at $34.3 \mathrm{~cm}$, decreased to 5.4 percent at $37.0 \mathrm{~cm}$, and increased to 6.2 percent at $40.8 \mathrm{~cm}$. The percent 
fines profile for Core P11B is shown in Figure 50. The percent fines content increased significantly with depth from 27.6 percent at $3.3 \mathrm{~cm}$ to 49.9 percent at $6.6 \mathrm{~cm}$, decreased with depth to 25.8 percent at $11.2 \mathrm{~cm}$ and 21.0 percent at $15.3 \mathrm{~cm}$, increased with depth to 38.2 percent at $19.5 \mathrm{~cm}$ and 43.5 percent at $25.1 \mathrm{~cm}$. Percent fines decreased with depth from $25.1 \mathrm{~cm}$ to a value of 31.9 percent at $30.5 \mathrm{~cm}$, increased significantly to 59.7 percent at $34.3 \mathrm{~cm}$, decreased significantly to 22.4 percent at $37.0 \mathrm{~cm}$, and decreased with depth to 28.7 percent at $40.8 \mathrm{~cm}$.

Erosion rates measured for a $0.8 \mathrm{~Pa}$ shear stress decreased with depth to $7 \mathrm{~cm}$ and increased between 7 and $13 \mathrm{~cm}$ (Figure 52). Erosion rates measured for 1.6 Pa shear stress increased consistently with depth from 4.5 to $14.4 \mathrm{~cm}$. Erosion rates for both the $0.8 \mathrm{~Pa}$ and 1.6 $\mathrm{Pa}$ shear stresses decreased with depth from 14.4 to $29 \mathrm{~cm}$, increased with depth from 29 to $36 \mathrm{~cm}$ depth, then decreased with depth to the bottom of the core.

The increase in erosion rates between 6.5 and $15 \mathrm{~cm}$ depth correlates to a decrease in the percent fines content over that layer of the core. The decrease in erosion rates from 15 to $29 \mathrm{~cm}$ correlates with an increase in percent fines content in that area of the core. Below $29 \mathrm{~cm}$, there is no clear correlation between erosion rate results and bulk properties.

\section{Core P12A}

Core P12A was $47.0 \mathrm{~cm}$ long. A $1 \mathrm{~cm}$ layer of dark material with some brown material mixed in was present at the surface. Below that layer, the core consisted of a fairly homogenous material for the remainder of the core, although the upper $11 \mathrm{~cm}$ of the main layer appeared to be slightly darker with some fine sand in it. Very large gas pockets were present throughout the core.

The bulk density profile for Core P12A is shown in figure 53. Density increased with depth from $1.27 \mathrm{~g} / \mathrm{cm}^{3}$ at $3.0 \mathrm{~cm}$ to $1.31 \mathrm{~g} / \mathrm{cm}^{3}$ at $6.1 \mathrm{~cm}$. Bulk density remained constant at $1.31 \mathrm{~g} / \mathrm{cm}^{3}$ to $12.1 \mathrm{~cm}$, increased to $1.33 \mathrm{~g} / \mathrm{cm}^{3}$ at $16.05 \mathrm{~cm}$, and decreased steadily with depth to $1.31 \mathrm{~g} / \mathrm{cm}^{3}$ at $22.4 \mathrm{~cm}$. Below $22.4 \mathrm{~cm}$, the profile was erratic; density increased with depth to $1.36 \mathrm{~g} / \mathrm{cm}^{3}$ at $24.9 \mathrm{~cm}$, decreased to $1.33 \mathrm{~g} / \mathrm{cm}^{3}$ at $27.7 \mathrm{~cm}$, increased to $1.38 \mathrm{~g} / \mathrm{cm}^{3}$ at $30.0 \mathrm{~cm}$, decreased to $1.33 \mathrm{~g} / \mathrm{cm}^{3}$ at $33.9 \mathrm{~cm}$ and $1.32 \mathrm{~g} / \mathrm{cm}^{3}$ at $36.6 \mathrm{~cm}$, increased to $1.37 \mathrm{~g} / \mathrm{cm}^{3}$ at $40.1 \mathrm{~cm}$, and decreased to $1.35 \mathrm{~g} / \mathrm{cm}^{3}$ at $44.4 \mathrm{~cm}$. The organic content of Core P12A decreased with depth from 7.1 percent at $3.0 \mathrm{~cm}$ to 6.4

percent at $6.1 \mathrm{~cm}$, and increased steadily with depth to 7.0 percent at $18.9 \mathrm{~cm}$ (Figure 54). Organic content decreased with depth to 5.2 percent at $24.9 \mathrm{~cm}$, increased to 6.9 percent at $27.6 \mathrm{~cm}$, decreased to 5.9 percent at $30.0 \mathrm{~cm}$, and increased to 6.8 percent at $33.9 \mathrm{~cm}$. Organic content decreased from $33.9 \mathrm{~cm}$ to $40.1 \mathrm{~cm}$, with values of 6.7 percent and 5.9 percent, respectively. Organic content remained constant at 5.9 percent to the bottom of the core. The percent fines content profile for Core P12A appears to be highly stratified (Figure 55). Percent fines decreased slightly with depth from 26.9 percent at $3.0 \mathrm{~cm}$ to 23.8 percent at $6.1 \mathrm{~cm}$, increased to 43.0 percent at $9.3 \mathrm{~cm}$ and 46.7 percent at $12.1 \mathrm{~cm}$. Fines decreased with depth below $12.1 \mathrm{~cm}$ to 31.0 percent at $16.0 \mathrm{~cm}$ and 27.2 percent at 
$18.9 \mathrm{~cm}$, increased significantly with depth to 57.5 percent at $22.4 \mathrm{~cm}$, decreased significantly to 27.2 percent at $24.9 \mathrm{~cm}$, and increased steadily to 38.2 percent at $30.0 \mathrm{~cm}$. Percent fines decreased with depth below $30.0 \mathrm{~cm}$ to 25.4 percent at $33.9 \mathrm{~cm}$, increased to 51.2 percent at $40.1 \mathrm{~cm}$, and decreased to 35.8 percent at $44.4 \mathrm{~cm}$.

Erosion rate results for $0.8 \mathrm{~Pa}, 1.6 \mathrm{~Pa}, 3.2 \mathrm{~Pa}$, and 4.5 $\mathrm{Pa}$ shear stresses showed an overall decreasing trend with depth, though there were some erratic results through the lower half of the core (Figure 56). While there are intervals of Core P12A where erosion rates appear to correlate to one bulk property, erosion rates consistently and simultaneously conflict with another bulk property. It was not possible to discern that one bulk property or another dominated erosion rate behavior for the core. It is possible that, as previously mentioned, variation in bulk properties between bulk sampling intervals influenced erosion rates.

\section{Core P12B}

Core P12B was $46 \mathrm{~cm}$ long. A $2 \mathrm{~mm}$ dark layer was present at the surface. Beneath that, a $1.5 \mathrm{~cm}$ dark brown layer was present that had black material mixed in with it. Below the dark brown layer there was a $5 \mathrm{~cm}$ thick grayish brown layer of sediment. Beneath the grayish brown sediment layer there was a brown layer that extended to the bottom of the core.

The bulk density profile for Core P12B increased with depth from $1.35 \mathrm{~g} / \mathrm{cm}^{3}$ at $3.5 \mathrm{~cm}$ to $1.40 \mathrm{~g} / \mathrm{cm}^{3}$ at $6.25 \mathrm{~cm}$, decreased to $1.34 \mathrm{~g} / \mathrm{cm}^{3}$ at $9.05 \mathrm{~cm}$, and increased steadily to $1.51 \mathrm{~g} / \mathrm{cm}^{3}$ at $23.3 \mathrm{~cm}$ (Figure 53). Bulk density decreased from $23.3 \mathrm{~cm}$ to $1.36 \mathrm{~g} / \mathrm{cm}^{3}$ at $31.2 \mathrm{~cm}$ and increased steadily to $1.49 \mathrm{~g} / \mathrm{cm}^{3}$ at $41.0 \mathrm{~cm}$. The organic content profile for Core P12B is presented in Figure 54. Organic content decreased slightly with depth from 5.8 percent at $3.5 \mathrm{~cm}$ to 5.6 percent at $6.2 \mathrm{~cm}$, increased to 6.8 percent at $9.0 \mathrm{~cm}$, and decreased to 4.1 percent at $15.3 \mathrm{~cm}$. Organic content decreased with depth below $15.3 \mathrm{~cm}$ to 5.2 percent at $23.2 \mathrm{~cm}$, increased to 7.0 percent at $31.2 \mathrm{~cm}$, and decreased to 5.7 percent at $41.0 \mathrm{~cm}$ depth. Percent fines content profile for Core P12B largely resembles that of Core P12A; however, fines percentage for Core P12B appear to consistently be about 10 to 15 percent lower (Figure 55). Percent fines decreased from 17.6 percent at $3.5 \mathrm{~cm}$ to 13.8 percent at $6.2 \mathrm{~cm}$, increased to 31.6 percent at $9.0 \mathrm{~cm}$, and decreased with depth to 14.5 percent at $23.2 \mathrm{~cm}$. Percent fines increased with depth below $23.2 \mathrm{~cm}$ to 26.6 percent at $31.2 \mathrm{~cm}$, decreased to 11.2 percent at $36.2 \mathrm{~cm}$, and increased to 21.4 percent at $41.0 \mathrm{~cm}$.

Erosion rate results for all shear stresses decreased with depth from the surface of Core P12B to $6.4 \mathrm{~cm}$ (Figure 57). Below $6.4 \mathrm{~cm}$, erosion rates for all shears increased with depth to about $18 \mathrm{~cm}$. Below $18 \mathrm{~cm}$, erosion rate results decreased with depth for all but the 6.4 Pa shear stress. Erosion rate results for shears below 3.2 Pa were no longer measurable below $18 \mathrm{~cm}$, and erosion rate results became immeasurable for the $3.2 \mathrm{~Pa}$ shear stress below $26 \mathrm{~cm}$ before curiously rebounding in regions of the core where the 6.4 Pa shear stress erosion rate results decreased with depth. 
The decrease in erosion rates to $6.4 \mathrm{~cm}$ depth and the increase in erosion rates from 6.35 to $18 \mathrm{~cm}$ depth correlate to trends in the percent fines content of Core P12B.

Increasing organic content may contribute to low to immeasurable erosion rates from 18 to $31 \mathrm{~cm}$ depth, and increasing bulk density is the only bulk parameter that correlates to erosion rate results below $31 \mathrm{~cm}$. The latter two correlations are not considered to be strong.

\section{Core P13A}

Core $13 \mathrm{~A}$ was $49.5 \mathrm{~cm}$ long. The same brown material was present throughout the core. The material appeared to be somewhat granular. There were large gas pockets throughout the core. The gas pockets were most prevalent in the upper $14 \mathrm{~cm}$ of the core. Leaves were visible at the surface of the core.

The bulk density profile for Core P13A was relatively constant with depth, never varying more than $0.1 \mathrm{~g} / \mathrm{cm}^{3}$ (Figure 58). Bulk density decreased with depth from $1.29 \mathrm{~g} / \mathrm{cm}^{3}$ at $6.0 \mathrm{~cm}$ to $1.22 \mathrm{~g} / \mathrm{cm}^{3}$ at $8.8 \mathrm{~cm}$, increased steadily to $1.27 \mathrm{~g} / \mathrm{cm}^{3}$ at $26.8 \mathrm{~cm}$, and decreased slightly to $1.25 \mathrm{~g} / \mathrm{cm}^{3}$ at $31.2 \mathrm{~cm}$. Density values increased with depth below $31.2 \mathrm{~cm}$ to $1.32 \mathrm{~g} / \mathrm{cm}^{3}$ at $38.8 \mathrm{~cm}$, and decreased steadily to $1.27 \mathrm{~g} / \mathrm{cm}^{3}$ at $43.3 \mathrm{~cm}$. Organic content increased significantly with depth from 7.0 percent at $6.0 \mathrm{~cm}$ to 11.4 percent at $8.8 \mathrm{~cm}$ (Figure 59). Below $8.8 \mathrm{~cm}$, organic content decreased with depth to 8.3 percent at $14.2 \mathrm{~cm}, 7.8$ percent at $20.0 \mathrm{~cm}$, and 5.6 percent at $26.8 \mathrm{~cm}$. Below $26.8 \mathrm{~cm}$, organic content increased with depth to 7.0 percent at $31.2 \mathrm{~cm}$ and 7.7 percent at $38.8 \mathrm{~cm}$, and decreased with depth to 7.3 percent at $40.6 \mathrm{~cm}$ and 7.1 percent at $43.3 \mathrm{~cm}$. The percent fines content profile for Core P13A is indicative of a stratified core with five distinct layers (Figure 60). Percent fines decreased from 17.7 percent at $6.0 \mathrm{~cm}$ to 9.0 percent at $8.8 \mathrm{~cm}$, increased with depth to 24.2 percent at $14.2 \mathrm{~cm}$ and 28.0 percent at $21.1 \mathrm{~cm}$. Below $21.1 \mathrm{~cm}$, percent fines decreased to 16.6 percent at $26.8 \mathrm{~cm}$, increased with depth to 35.6 percent at $31.2 \mathrm{~cm}$, decreased to 21.6 percent at $38.8 \mathrm{~cm}$, and increased to 22.2 percent at $40.6 \mathrm{~cm}$ and 29.3 percent at $43.3 \mathrm{~cm}$.

Core P13A showed very little resistance to erosion (Figure 61). Erosion rates decreased with depth to $15.3 \mathrm{~cm}$, increased with depth to $25.9 \mathrm{~cm}$, and decreased with depth to $31.6 \mathrm{~cm}$. Below $31.6 \mathrm{~cm}$, erosion rates again increased with depth to $41.3 \mathrm{~cm}$, below which erosion rates decreased with depth.

The erosion rate results for Core P13A correlate very well with percent fines content data, though cursory inspection of Figure 60 (Core P13A fines content) may not lead to that conclusion. It is important to note that while Figure 60 includes lines connecting the data points for clarity, the lines have no real meaning. The distribution of real data between the data points may have a much different profile than what the connecting lines imply, especially if there is significant space between data points. 


\section{Core P13B}

Core P13B was $44.0 \mathrm{~cm}$ long. Several leaves were present at the top of the core. A 1 to $2 \mathrm{~mm}$ black layer was present at the surface of the core. Below that layer a light brown material mixed with sand was present to $8.5 \mathrm{~cm}$ depth. Several gas pockets and some leaves were visible in the mixed sand layer. Below that layer, a light brown material extended to the bottom of the core. Several gas pockets were visible in the bottom light brown layer.

Though the bulk density profile for Core P13B was more erratic with depth than that of Core P13A, the bulk density values for the core similarly never varied more than $0.1 \mathrm{~g} / \mathrm{cm}^{3}$ (Figure 58). Bulk density decreased slightly with depth from $1.27 \mathrm{~g} / \mathrm{cm}^{3}$ at $2.8 \mathrm{~cm}$ to $1.26 \mathrm{~g} / \mathrm{cm}^{3}$ at $6.6 \mathrm{~cm}$, increased to $1.31 \mathrm{~g} / \mathrm{cm}^{3}$ at $9.2 \mathrm{~cm}$, decreased to $1.25 \mathrm{~g} / \mathrm{cm}^{3}$ at $16.7 \mathrm{~cm}$, remained relatively constant to $20.8 \mathrm{~cm}$, and decreased with depth to $1.23 \mathrm{~g} / \mathrm{cm}^{3}$ at $24.0 \mathrm{~cm}$. Below $24.0 \mathrm{~cm}$, density increased with depth to $1.31 \mathrm{~g} / \mathrm{cm}^{3}$ at $27.6 \mathrm{~cm}$ and $1.33 \mathrm{~g} / \mathrm{cm}^{3}$ at $31.5 \mathrm{~cm}$, decreased to $1.29 \mathrm{~g} / \mathrm{cm}^{3}$ at $34.7 \mathrm{~cm}$ and $1.26 \mathrm{~g} / \mathrm{cm}^{3}$ at $34.9 \mathrm{~cm}$. The trends and values of the organic content for Core P13B closely followed those of Core P13A (Figure 59). Organic content decreased from 7.4 percent at $2.8 \mathrm{~cm}$ to 6.2 percent at $6.6 \mathrm{~cm}$, and increased with depth to 9.4 percent at $9.2 \mathrm{~cm}$. Organic content decreased with depth to 7.9 percent at $13.4 \mathrm{~cm}$, remained relatively constant to $16.7 \mathrm{~cm}$, increased to 8.5 percent at $20.8 \mathrm{~cm}$, and decreased with depth to 7.8 percent at $24.0 \mathrm{~cm}$. Organic content remained relatively constant from $24.0 \mathrm{~cm}$ to $27.6 \mathrm{~cm}$, decreased with depth to 6.0 percent at $31.5 \mathrm{~cm}$, increased to 8.1 percent at $34.7 \mathrm{~cm}$, and decreased to 7.7 percent at $39.4 \mathrm{~cm}$. The percent fines content profile for Core P13B is highly erratic with large magnitude shifts in fines content, and the profile is indicative of a highly stratified core with many distinct layers (Figure 60). Percent fines increased with depth from 14.4 percent at $2.8 \mathrm{~cm}$ to 29.3 percent at $6.6 \mathrm{~cm}$, decreased to 13.5 percent at $9.2 \mathrm{~cm}$, increased significantly to 44.5 percent at $13.4 \mathrm{~cm}$ and 49.7 percent at $16.7 \mathrm{~cm}$. Percent fines content decreased with depth below $16.7 \mathrm{~cm}$ to 30.6 percent at $20.8 \mathrm{~cm}$, increased significantly to 57.3 percent at $24.0 \mathrm{~cm}$, decreased significantly to 22.1 percent at $27.6 \mathrm{~cm}$ and 7.1 percent at $31.5 \mathrm{~cm}$, and increased significantly to 24.3 percent at $34.7 \mathrm{~cm}$ and 46.8 percent at $39.4 \mathrm{~cm}$.

Core P13B was much more resistant to erosion (Figure 62) than the nearby core, Core P13A. Erosion rates decreased with depth to $19 \mathrm{~cm}$, below which erosion rates increased slightly to $25 \mathrm{~cm}$. Erosion rates decreased with depth from $25 \mathrm{~cm}$ to $27.8 \mathrm{~cm}$ and from $27.8 \mathrm{~cm}$ to the bottom of the core.

The overall decreasing trend in erosion rates for the top $27 \mathrm{~cm}$ of the core correlates to the overall increasing percent fines content through those depths, however the lowest 3.2 Pa erosion rate was counter intuitively measured right after a sandier bulk property sample was taken at $27.6 \mathrm{~cm}$. The increasing erosion rates with depth measured below $27 \mathrm{~cm}$ do not correlate well with any bulk property. Bulk density decreases in that region; however, organic content and percent fines increase which almost always lead to decreased erosion rates. 


\section{Core P14A}

Core P14A was $34 \mathrm{~cm}$ long. A $2 \mathrm{~mm}$ black layer was present at the surface. Gas pockets were prevalent throughout the core. A horizontal fracture that spanned the entire core appeared to be present at $4 \mathrm{~cm}$ depth. The material in the top $11 \mathrm{~cm}$ was dark brown and appeared to have sand in it. Below $11 \mathrm{~cm}$ depth, a lighter brown layer of sediment was present that extended to the bottom of the core.

The bulk density profile for Core P14A is shown in Figure 63. Density decreased with depth from $1.55 \mathrm{~g} / \mathrm{cm}^{3}$ at $1.7 \mathrm{~cm}$ to $1.37 \mathrm{~g} / \mathrm{cm}^{3}$ at $5.8 \mathrm{~cm}$ and $1.34 \mathrm{~g} / \mathrm{cm}^{3}$ at $10.2 \mathrm{~cm}$. Bulk density remained constant at $1.34 \mathrm{~g} / \mathrm{cm}^{3}$ to $13.4 \mathrm{~cm}$, increased to $1.44 \mathrm{~g} / \mathrm{cm}^{3}$ at $17.2 \mathrm{~cm}$ and $1.48 \mathrm{~g} / \mathrm{cm}^{3}$ at $22.7 \mathrm{~cm}$, increased significantly to $1.83 \mathrm{~g} / \mathrm{cm}^{3}$ at $26.1 \mathrm{~cm}$ and decreased to a density value more in line with those seen in rest of the core, $1.43 \mathrm{~g} / \mathrm{cm}^{3}$ at $29.5 \mathrm{~cm}$. The organic content profile for Core P14A is presented in Figure 64. Organic content increased with depth from 1.95 percent at $1.7 \mathrm{~cm}$ to 7.0 percent at $5.8 \mathrm{~cm}$, decreased to 6.0 percent at $10.2 \mathrm{~cm}$, and increased to 7.4 percent at $13.4 \mathrm{~cm}$. The organic content profile decreased steadily with depth below $13.4 \mathrm{~cm}$ to 0.6 percent at $26.1 \mathrm{~cm}$, and then increased to 4.0 percent at $29.5 \mathrm{~cm}$. The percent fines content profile for Core P14A showed two layers of almost pure sand broken up by a layer of about ten percent fines (Figure 65). Percent fines increased from 0.6 percent at $1.7 \mathrm{~cm}$ to 0.8 percent at $5.8 \mathrm{~cm}$, increased more significantly with depth to 7.3 percent at $10.2 \mathrm{~cm}$ and 9.3 percent at $13.4 \mathrm{~cm}$. Below $13.4 \mathrm{~cm}$, percent fines decreased steadily to 0.5 percent at $22.7 \mathrm{~cm}$, decreased to nearly zero at $26.1 \mathrm{~cm}$, and increased to 5.5 percent at $29.5 \mathrm{~cm}$.

Erosion rate results for $0.4,0.8$, and $1.6 \mathrm{~Pa}$ all decreased slightly with depth initially, but decreased significantly with depth and became immeasurably small in the top $23 \mathrm{~cm}$ of the core (Figure 66). In the most erosion resistant part of the core, between 6.3 and $21.1 \mathrm{~cm}$, two 3.2 Pa erosion rates were measured. The $3.2 \mathrm{~Pa}$ erosion rates also showed a decreasing trend with depth. Erosion rates increased with depth from 24 to $25 \mathrm{~cm}$, below which they again decreased with depth. The erosion rate results for Core P14A correspond intuitively to the percent fines content distribution.

\section{Core P14B}

Core P14B was $33.5 \mathrm{~cm}$ long. A large twig was present on the surface of the core. Dark brown material with sand and leaves mixed in was present to $8 \mathrm{~cm}$ depth. Below $8 \mathrm{~cm}$ depth, the core consisted of dark brown material with pockets of visible sand and gas.

The bulk density profile for Core P14B followed that of Core P14A very closely for the upper $15 \mathrm{~cm}$ of the core (Figure 63). Below a depth of $15 \mathrm{~cm}$, the bulk density profiles of the two cores were highly divergent. Bulk density decreased with depth from $1.56 \mathrm{~g} / \mathrm{cm}^{3}$ at $2.2 \mathrm{~cm}$ to $1.40 \mathrm{~g} / \mathrm{cm}^{3}$ at $5.1 \mathrm{~cm}$ and $1.38 \mathrm{~g} / \mathrm{cm}^{3}$ at $9.5 \mathrm{~cm}$. Bulk density remained constant at $1.38 \mathrm{~g} / \mathrm{cm}^{3}$ between depths of $9.5 \mathrm{~cm}$ and $12.6 \mathrm{~cm}$, increased to $1.42 \mathrm{~g} / \mathrm{cm}^{3}$ at $15.0 \mathrm{~cm}$, and decreased steadily to $1.19 \mathrm{~g} / \mathrm{cm}^{3}$ at $21.8 \mathrm{~cm}$. Density decreased with depth to $1.27 \mathrm{~g} / \mathrm{cm}^{3}$ at $25.1 \mathrm{~cm}$ and remained relatively constant to the 
lowermost measurement of the core at $29.7 \mathrm{~cm}$. Similar to the bulk density profile, the organic content profile of Core P14B closely resembled that of Core P14A for the top $15 \mathrm{~cm}$ of the core, below which there was no resemblance between the profiles of the two cores (Figure 64). Organic content increased steadily with depth from 4.4 percent at $2.2 \mathrm{~cm}$ to 6.6 percent at $9.5 \mathrm{~cm}$, decreased to 5.7 percent at $12.6 \mathrm{~cm}$, increased to 7.8 percent at $15.0 \mathrm{~cm}$, and decreased slightly to 7.3 percent at $18.4 \mathrm{~cm}$. Organic content spiked to 19.7 percent at $21.8 \mathrm{~cm}$, and decreased steadily to 10.1 percent at $29.7 \mathrm{~cm}$. The percent fines content profile for Core P14B showed little resemblance to that of P14A (Figure 65). Percent fines increased with depth from 0.9 percent at $2.2 \mathrm{~cm}$ to 4.6 percent at $9.5 \mathrm{~cm}$, decreased with depth to 2.6 percent at $12.6 \mathrm{~cm}$ and 2.4 percent at $15.0 \mathrm{~cm}$, and increased to 5.7 percent at $18.4 \mathrm{~cm}$ and 12.9 percent at $21.8 \mathrm{~cm}$. Percent fines remained relatively constant between $21.8 \mathrm{~cm}$ and $25.1 \mathrm{~cm}$, and increased to 20.0 percent at $29.7 \mathrm{~cm}$.

Core P14B showed very little resistance to erosion (Figure 67). Erosion rates decreased with depth from the surface of the core to $6.5 \mathrm{~cm}$ depth. Erosion rates increased with depth between 6.5 and $10.75 \mathrm{~cm}$ depth, decreased with depth between 10.75 and $13.33 \mathrm{~cm}$ depth, then increased with depth between 13.33 and $16.2 \mathrm{~cm}$ depth. The erratic erosion rate behavior continued below $16.2 \mathrm{~cm}$, as erosion rates decreased between 16.2 and $18.75 \mathrm{~cm}$ depth, then increased between 18.75 and $24.5 \mathrm{~cm}$ depth, then decreased with depth to the bottom of the core. The increasing percent fines content of core P14B might suggest decreasing erodibility with depth. That trend is indeed observed in the 0.8 and 1.6 $\mathrm{Pa}$ shear stress results; the spikes in erosion rates at about 16 and $24 \mathrm{~cm}$ depth are a result of small layers of excessive gas content and leafy debris, respectively.

\section{Core P15A}

Core P15A was $50 \mathrm{~cm}$ long. A $3 \mathrm{~mm}$ floc layer was present at the surface of the core. A 2 to $3 \mathrm{~cm}$ layer of dark, fine-grained looking material was present on one side of the core, but not the other. Beneath that layer was $34 \mathrm{~cm}$ of what appeared to be pure sand. A $14 \mathrm{~cm}$ layer of very dark material was present at the bottom of the core. No sand was visible in that layer.

The bulk density values of Core P15A were extremely high for most of the core (Figure 68). Bulk density decreased steadily with depth from $1.89 \mathrm{~g} / \mathrm{cm}^{3}$ at $3.4 \mathrm{~cm}$ to $1.83 \mathrm{~g} / \mathrm{cm}^{3}$ at $12.9 \mathrm{~cm}$, increased to $1.91 \mathrm{~g} / \mathrm{cm}^{3}$ at $16.7 \mathrm{~cm}$, and remained constant at $1.91 \mathrm{~g} / \mathrm{cm}^{3}$ to $22.0 \mathrm{~cm}$. Below $22.0 \mathrm{~cm}$, density decreased with depth to $1.84 \mathrm{~g} / \mathrm{cm}^{3}$ at $28.3 \mathrm{~cm}$, remained relatively constant to $34.6 \mathrm{~cm}$, and decreased significantly to $1.29 \mathrm{~g} / \mathrm{cm}^{3}$ at $35.2 \mathrm{~cm}$. The organic content profile for Core P15A is presented in Figure 69. Organic content increased slightly with depth from 0.5 percent at $3.4 \mathrm{~cm}$ to 0.8 percent at $16.7 \mathrm{~cm}$. Organic content increased with depth to 1.5 percent at $22.0 \mathrm{~cm}$ and 4.8 percent at $28.3 \mathrm{~cm}$, decreased to 1.2 percent at $34.6 \mathrm{~cm}$, and increased significantly to 9.2 percent at $35.2 \mathrm{~cm}$. The percent fines profile for Core P15A shows that the core was virtually pure sand from 3.4 to $12.9 \mathrm{~cm}$ (Figure 70). Percent fines increased with depth to 
2.9 percent at $16.7 \mathrm{~cm}$ and increased steadily to 4.3 percent at $28.3 \mathrm{~cm}$. Below $28.3 \mathrm{~cm}$, percent fines decreased to 1.0 percent at $34.6 \mathrm{~cm}$, and increased significantly to 30.4 percent at $35.2 \mathrm{~cm}$.

Core P15A was extremely susceptible to erosion at low shear stresses (Figure 71). Erosion rates showed a decreasing trend with depth from the surface of the core to $17.7 \mathrm{~cm}$ depth. Erosion rates for the 1.6 Pa shear stress showed a sharp drop at $13.6 \mathrm{~cm}$ depth. Erosion rates increased with depth between $17.7 \mathrm{~cm}$ and $27.1 \mathrm{~cm}$, decreased sharply at about $29 \mathrm{~cm}$, and increased with depth to $32.1 \mathrm{~cm}$ depth. Below $32.1 \mathrm{~cm}$, shear stresses up to $8.0 \mathrm{~Pa}$ failed to result in measurable erosion rates. The erosion rate results for Core P15A correlate well with the percent fines content data. The drop in erosion rates around $15 \mathrm{~cm}$ corresponds to a significant increase in fines content at that depth, and the transition to the dark, cohesive sediment lower layer is clearly reflected in the extreme decrease in erodibility and increase in fines content at the $35 \mathrm{~cm}$ depth.

\section{Core P15B}

Core P15B was $47.5 \mathrm{~cm}$ long. A $1 \mathrm{~mm}$ floc layer was present at the surface of the core. Below the floc layer a $34 \mathrm{~cm}$ mixture of coarse sandy material and fine grained material was present. Below the sandy layer a $12 \mathrm{~cm}$ thick layer of dark, fine-grained material was present.

The bulk density profile for Core P15B is extremely similar to that of Core P15A, including the very significant decrease in bulk density at the lowermost point in the core (Figure 63). Bulk density remained relatively constant at about $1.89 \mathrm{~g} / \mathrm{cm}^{3}$ from $5.3 \mathrm{~cm}$ to $19.2 \mathrm{~cm}$. Bulk density decreased with depth to $1.81 \mathrm{~g} / \mathrm{cm}^{3}$ at $25.4 \mathrm{~cm}$, increased steadily to $1.89 \mathrm{~g} / \mathrm{cm}^{3}$ at $31.6 \mathrm{~cm}$, decreased to $1.84 \mathrm{~g} / \mathrm{cm}^{3}$ at $34.4 \mathrm{~cm}$, and decreased significantly to $1.2 \mathrm{~g} / \mathrm{cm}^{3}$ at $36.5 \mathrm{~cm}$. As with the bulk density profile, the organic content profile of Core P15B very closely matched that of Core P15A, although the organic value of the extreme lowermost point was significantly larger for Core P15B (Figure 64). Organic content increased from 0.5 percent at $5.3 \mathrm{~cm}$ to 1.0 percent at $10.6 \mathrm{~cm}$ depth and decreased with depth to 0.8 percent at $19.2 \mathrm{~cm}$. Below $19.2 \mathrm{~cm}$, organic content increased to 4.4 percent at $25.4 \mathrm{~cm}$, decreased to 1.2 percent at $28.8 \mathrm{~cm}$ and 0.8 percent at $31.5 \mathrm{~cm}$. Organic content increased slightly with depth to 0.9 percent at $34.4 \mathrm{~cm}$, and increased significantly to 12.3 percent at $36.5 \mathrm{~cm}$. Contrary to the bulk density and organic content profiles, the percent fines profiles of Cores P15A and P15B differed significantly between 10 and $19 \mathrm{~cm}$ (Figure 70). Core P15B was nearly pure sand from 5.3 to $10.6 \mathrm{~cm}$. The percent fines increased by a very large amount to 46.6 percent at $15.7 \mathrm{~cm}$, and decreased to 2.0 percent at $19.2 \mathrm{~cm}$. Below $19.2 \mathrm{~cm}$, percent fines increased with depth to 7.1 percent at $25.4 \mathrm{~cm}$, decreased steadily to 0.3 percent at $31.6 \mathrm{~cm}$, and increased significantly to 35.3 percent at $36.5 \mathrm{~cm}$.

Erosion rates decreased with depth between 1.6 and $5.5 \mathrm{~cm}$ depth and increased with depth between 5.5 and $11.1 \mathrm{~cm}$ (Figure 72). Erosion rates remained relatively constant with depth down to $28.9 \mathrm{~cm}$, where an erosion resistant layer was encountered which did not measurably erode at 0.8 and 1.6 Pa shear stresses. Between 31.8 and $33.2 \mathrm{~cm}$, 
erosion rates for 0.8 and 1.6 Pa rebounded to values consistent with the middle of the core. Below $33.2 \mathrm{~cm}$, a layer of cohesive sediment was reached which prohibited measurable erosion up to shear stresses of 8.0 Pa. The erosion rate results for Core P15B correlate well with the percent fines content data. The large increase in fines content observed in Core P15A at about $15 \mathrm{~cm}$ is not seen in the grain size data for Core P15B, and as expected the erosion rate results do not decrease in that region. The transition from sand to cohesive sediment at about $35 \mathrm{~cm}$ depth is clear. 


\section{Summary and Conclusions}

Twenty-eight sediment cores from 14 sites along the Passaic River, NJ were captured, eroded in the USACE Sedflume, sampled for bulk property analysis. The results of the bulk property analysis and erosion rate experiments have been presented and correlated to one another.

Sediment cores from sites P01 through P05 were nominally about 30 to 40 percent fines and measured erosion rates of less than $1 \mathrm{e}-02 \mathrm{~cm} / \mathrm{s}$ for a $3.2 \mathrm{~Pa}$ shear stress.

Sediment cores at $\mathrm{P} 07$ were influenced by organic content, and percent fines influenced cores at sites P06, P08, and P09, although Core P09B appeared to be related to bulk density. Additionally, sediment cores from sites P06 through P09 contained leaves and pockets of trapped gas that influenced several of the erosion rates. Sediment cores from sites P11, P14, and P15 were very susceptible to erosion at low shear stresses, while cores from sites P12 and P13 showed resistance to erosion that was similar to that of the Site P01 through P05 cores.

Noteworthy heterogeneity was often observed between replicate cores from the same sampling site. Actual replicate coring locations varied in distance from about 1 to $10 \mathrm{~m}$. 


\section{References}

Borrowman, T.D., Smith, E.R., and Gailani, J. Z. (2005). "Sediment erosion study for the Palos Verdes Shelf effluent affected sediment," Report submitted to the U.S. Army Corps of Engineers, Los Angeles District, U.S. Army Engineer Research and Development Center, Vicksburg, MS.

Jepsen, R., Roberts, J., and Lick, W. (1997a). "Effects of bulk density on sediment erosion rates," Water, Air, and Soil Pollution, 99: 21-31.

Jepsen, R., Roberts, J., and Lick, W. (1997b). "Long Beach Harbor sediment study," Report submitted to U.S. Army Corps of Engineers, Los Angeles District, DACW09-97-M-0068

Jepsen, R., Roberts, J., Lick, W., Gotthard, D., and Trombino, C. (1998). "New York Harbor sediment study," Report submitted to the U.S. Army Corps of Engineers, New York District.

McNeil, J., Taylor, C., and Lick, W. (1996). "Measurements of the erosion of undisturbed bottom sediments with depth," Journal of Hydraulic Engineering, 122 (6): 316-324.

Roberts, J., Jepsen, R., Gotthard, D., and Lick, W. (1998). "Effects of particle size and bulk density on erosion of quartz particles," Journal of Hydraulic Engineering, 124(12): 1261-1267.

Schlichting, H. (1979). Boundary-layer theory. Seventh ed, McGraw-Hill. 